\title{
Local stress anomaly in the Bavarian Molasse Basin
}

\author{
Robin Seithel ${ }^{1 *}$, Ulrich Steiner ${ }^{2}$, Birgit Müller ${ }^{1}$, Christian Hecht ${ }^{3}$ and Thomas Kohl ${ }^{1}$
}

\footnotetext{
* Correspondence: robin.seithel@kit.edu ${ }^{1}$ Karlsruher Institute of Technology (KIT), Adenauerring 20b, 76131 Karlsruhe, Germany Full list of author information is available at the end of the article
}

\begin{abstract}
Background: The characterization of fault zones in the Bavarian Molasse Basin plays a major role for further geothermal reservoir development. Hence, their identification, geological origin, and hydraulic characterization are discussed extensively.

Methods: Stress indicators and fractures are interpreted from image and caliper logs of three highly deviated wells at the Sauerlach site. We transform the identified stress field into the borehole coordinate system and compare the observed orientation to the modeled stress field which assumes a homogeneous borehole surrounding.

Results: High breakout occurrence, cross-cutting fractures, and a fracture orientation from N-S to NNE-SSW are observed in Sauerlach Th1. In Sauerlach Th2 and Th3, fractures strike primarily ENE-WSW and N-S to NNE-SSW. Drilling-enhanced natural fractures and drilling-induced tensile fractures are observed in all three wells and indicate the orientation of tensile stress at the borehole wall. In Sauerlach Th2 and Th3, stress transformation indicates a $\mathrm{S}_{\mathrm{H}^{-}}$-dir. $\sim \mathrm{N} 10^{\circ} \mathrm{E}$ in a strike-slip stress regime. The modeled stress orientations match the observed orientations within the well Sauerlach Th1 if either $\mathrm{S}_{\mathrm{H}^{-}}$dir. is $\mathrm{N} 320^{\circ} \mathrm{E}$ in a strike-slip regime or $\mathrm{S}_{\mathrm{H}^{-}}$-dir. is $\mathrm{N} 10^{\circ} \mathrm{E}$ in a normal faulting regime.
\end{abstract}

Conclusion: This approach improves the detection of the local stress field especially for non-vertical wells, which has, in combination with the facture pattern, a major impact on the hydraulic system of the geothermal reservoir.

\section{Background}

The use of geothermal energy in the Bavarian Molasse Basin started in the late 1990s when first district heating projects emerged. To encourage further development of geothermal energy use, the Bavarian Geothermal Atlas was published in 2004. Indeed, this led to an increased exploration activity for heat and power generation. For geothermal district heating projects, an incentive program followed on the national level, resulting in a total of 12 successfully developed district heating projects with an installed thermal capacity of $141.1 \mathrm{MW}_{\text {th }}$ so far. After the first power generation project in 2004, three more projects followed after 2008/2009 in the area south of Munich, the installed capacity being 22.36 $\mathrm{MW}_{\mathrm{el}}$ and $42 \mathrm{MW}_{\text {th }}$ (GTV 2014; Dorsch and Pletl 2012).

The Bavarian Molasse Basin offers favorable conditions for the utilization of geothermal energy. Among a total number of 46 wells, 44 were operated successfully. The initial exploration strategy focused on faults and fault zones. They were identified mainly based on old seismic industry data showing an offset of significant reflectors especially 
at the base of the Tertiary strata. With advancing reservoir knowledge resulting from the evaluation of the drilled geothermal wells and the acquisition of new seismic data, the lithofacial aspects of the Malm reservoir were studied. The findings were incorporated in the exploration strategy (Boehm et al. 2012; Lueschen et al. 2014). Nevertheless, the two failed drillings still give rise to questions with respect to diagenetic processes, along with dolomitization as well as hydraulically active fractures and faulting. A key aspect towards an improved evaluation of reservoir rock properties of the Malm is the integration of stress field parameters, since critically stressed fractures are known to be more often hydraulically active than uncritically stressed fractures (Barton et al. 1995).

It is well known that the major geothermal provinces are located at structurally favorable settings dominated by step-over/transferring, overlapping, or terminating normal faults. They are preferably striking parallel to the maximum horizontal stress (Faulds et al. 2011). The majority of the Molasse basin fault zones identified are ENE-WSW-trending normal faults (Lemcke 1988). In relation to the roughly N-S-oriented maximum horizontal stress (Reinecker et al. 2010), the N-S or NNE-SSW (approximately N 30 E)-oriented fracture systems show a high tendency to develop tensile or shearing character. Recent seismic investigations revealed inhomogeneities near normal faults, which may have a significant impact on the hydraulic properties of the reservoir (Lueschen et al. 2014).

In order to study fracture systems, stress indicators, and facies structures within the reservoir, image logs can be used (Shamir and Zoback 1992; Hickman and Zoback 2004). This study covers three wells of the Sauerlach site with highly deviated reservoir sections. Their fracture sets as well as stress indicators (drilling-induced tensile fractures (DITF), drilling-enhanced natural fractures (DENF), and breakouts (BO)) are interpreted in the image logs. For highly deviated wells, in situ stress interpretation based on stress indicators is carried out by transforming the regional stress field into the wellbore coordinate system. Our approach is to compare the observed orientations from the different stress indicators with the calculated (modeled) stress orientations. For the regional stress field, we generally assumed a strike-slip stress regime (Reinecker et al. 2010). The difference between the orientation of the interpreted stress indicators and the calculated stress distribution in the well can be determined. By varying the stress regime, the difference between the observed and calculated stress direction is minimized to study the local stress field near the wells.

\section{The geothermal Sauerlach project}

We analyzed data from the geothermal project at Sauerlach which is situated SE of Munich. It is one of the biggest heat- and power-supplying geothermal project in Germany (GTV 2014) and is operated by the Munich utility company Stadtwerke München. Three wells, two for injection (Sauerlach Th2 and Th3) and one for production (Sauerlach Th1), were drilled in 2008 and 2009 . The production yield is $110 \mathrm{~L} / \mathrm{s}$ with a temperature of $140^{\circ} \mathrm{C}$ from the $4 \mathrm{~km}$ deep reservoir (Pletl et al. 2010). Under present conditions, an about $4 \mathrm{MW}_{\mathrm{e}}$ of electrical power and a maximum heat production of $4 \mathrm{MW}_{\text {th }}(4 \mathrm{GWh} / \mathrm{a})$ are supplied. The plant has been connected to the grid since spring 2014.

All three wells are drilled from one drill pad with a nearly vertical orientation down to $1,000 \mathrm{~m}$ depth. Starting with the third well section, they are inclined in the direction of the reservoir targets: Sauerlach Th1 is oriented to NW-SE (N 300 ${ }^{\circ}$ ) with an inclination between $50^{\circ}$ and $60^{\circ}$ (from the vertical) and reaches the reservoir at a depth of 3,739 $\mathrm{m}$ TVD (Figure 1a/red point). Sauerlach Th2 reaches the reservoir at 3,571 m 


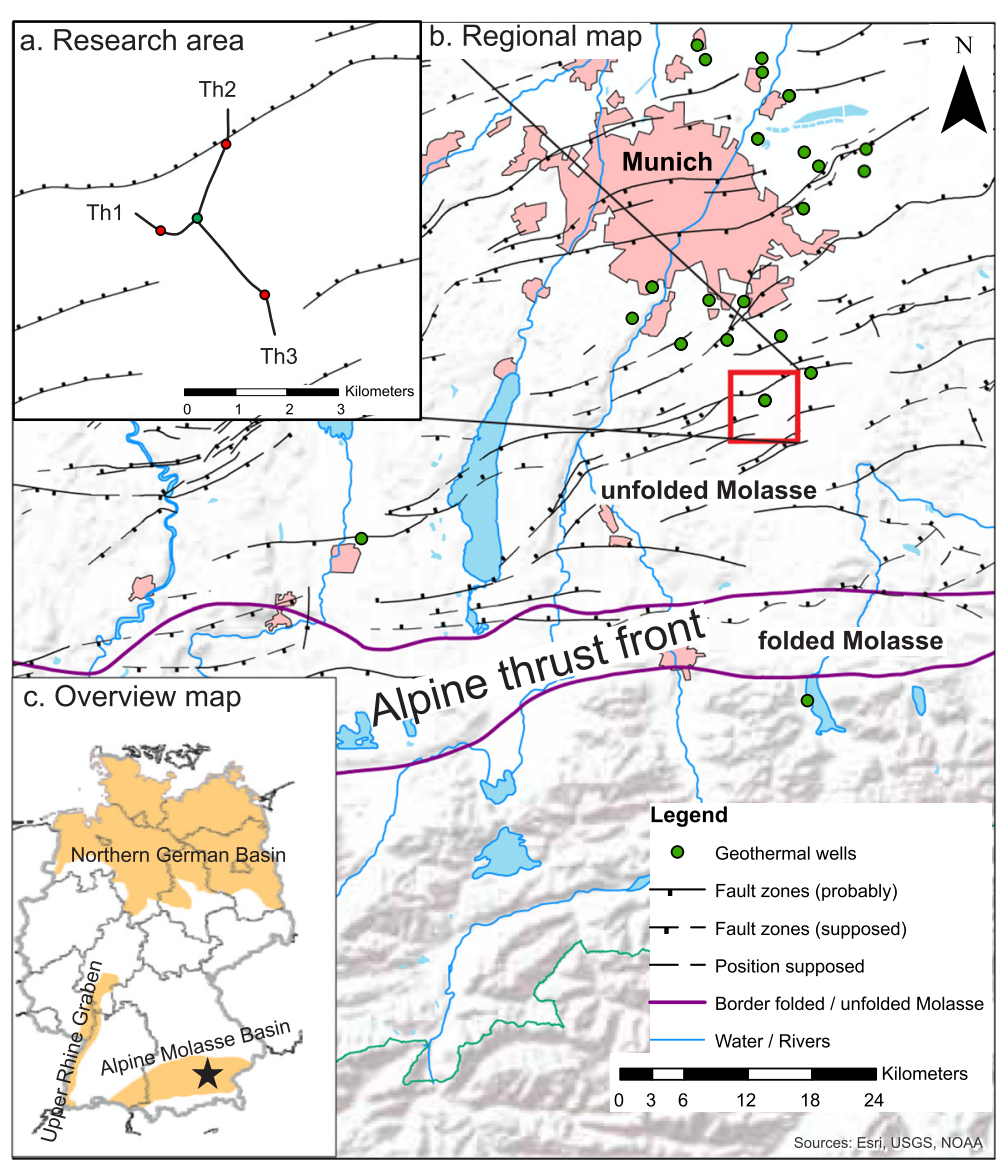

Figure 1 Study area and tectonic background. a. Map with well trajectories of Th1, Th2, and Th3 and the top of the reservoir section marked by red points as well as fault zones of the Geothermie Atlas (STWIVT 2010). b. Map of the region south of Munich with the tectonic sections of the unfolded and folded Molasse Basin, geothermal wells, and the fault zones found in the tertiary structures of the Geothermie Atlas. c. Overview map from Geotis (Schulz et al. 2009) and the investigation area marked by a black asterisk.

TVD (Figure 1a/red point) and is directed towards $\mathrm{N}\left(\mathrm{N}^{\circ} \mathrm{E}\right)$ with an inclination between $40^{\circ}$ and $60^{\circ}$. Sauerlach Th3 reaches the reservoir at 3,872 $\mathrm{m}$ TVD and is oriented to $\operatorname{SSE}\left(\mathrm{N} 160^{\circ} \mathrm{E}\right)$ (Figure 1a/red point) with an inclination between $35^{\circ}$ and $60^{\circ}$.

Directly after drilling, 6-arm caliper (Schlumberger EMS-GR, Houston, TX) and image logs (Schlumberger FMI, Houston, TX) were measured to image the borehole wall (Table 1). In addition, drilling safety tests, such as formation integrity tests (FIT), and the reports of cementation jobs revealed borehole pressure data indicating the lower bound of the minimum principle stress magnitude.

Well test analysis shows a considerably higher productivity of Sauerlach Th1 compared to Sauerlach Th2 and Th3, although permeability values of the reservoir in all three wells were similar. A dominant radial flow regime underlines the significance of matrix porosity to reservoir characterization in all three wells during expansion of the depression cone. However, additional to its better productivity, Sauerlach Th1 stands out with its very high negative skin effect at the very beginning of pumping, which is an indicator of a good hydraulic connection between the borehole and the reservoir (personal communication Savvatis 2014). 
Table 1 Database for structural and stress interpretation of well logs

\begin{tabular}{lccccc}
\hline Well & Tool & $\begin{array}{c}\text { Hole } \\
\text { diameter }\end{array}$ & $\begin{array}{c}\text { Hole azimuth/ } \\
\text { inclination }\end{array}$ & $\begin{array}{c}\text { Depth interval } \\
\text { (MD) }\end{array}$ & $\begin{array}{c}\text { Depth interval } \\
\text { (TVD) }\end{array}$ \\
\hline Th1 & EMS-GR (6-arm caliper) & $23^{\prime \prime}$ & Vertical & 49 to $987 \mathrm{~m}$ & 49 to $987 \mathrm{~m}$ \\
& EMS-GR (6-arm caliper) & $16^{\prime \prime}$ & Vertical & 982 to $2,351 \mathrm{~m}$ & 982 to $2,351 \mathrm{~m}$ \\
& EMS-GR (6-arm caliper) & $12^{\prime \prime}$ & Vertical to $230^{\circ}$ to $290^{\circ} / 45^{\circ}$ & 2,346 to $3,990 \mathrm{~m}$ & 2,351 to $3,739 \mathrm{~m}$ \\
& FMl & $8,5^{\prime \prime}$ & $300^{\circ} / 45^{\circ}$ to $60^{\circ}$ & 3,981 to $4,757 \mathrm{~m}$ & 3,739 to $4,177 \mathrm{~m}$ \\
Th2 & FMI & $8,5^{\prime \prime}$ & $0^{\circ} / 45^{\circ}$ to $60^{\circ}$ & 4,025 to $4,850 \mathrm{~m}$ & 3,571 to $4,086 \mathrm{~m}$ \\
Th3 & FMI & $6,125^{\prime \prime}$ & $160^{\circ} / 45^{\circ}$ to $60^{\circ}$ & 4,343 to $5,490 \mathrm{~m}$ & 3,872 to $4,438 \mathrm{~m}$ \\
\hline
\end{tabular}

\section{Reservoir geology}

The Upper Jurassic (Malm) forms the major hydrothermal reservoir in Bavarian Molasse Basin. In the Munich area, it reaches depths between 2,000 and 4,000 m, while the thickness is about $550 \mathrm{~m}$. With temperatures between $80^{\circ}$ and $140^{\circ} \mathrm{C}$ and a low salinity, favorable conditions exist for heat and power generation (STWIVT 2010). The Malm is located below the Bavarian Molasse Basin as part of the North Alpine Foreland Basin. The Bavarian Molasse Basin evolved as a typically wedge-shaped foreland basin from the Upper Eocene to the Upper Miocene in response to Alpine tectonics accompanied by erosion and uplift (Kuhlemann and Kempf 2002).

Hydrogeologically speaking, the Malm exhibits the behavior typical of carbonatic aquifers, with a complex interaction of karstification, fracture, and matrix porosity, where structural and lithofacial properties determine the productivity of the wells (Lueschen et al. 2014; Steiner et al. 2014).

The Malm lithology is characterized by two major sedimentation cycles with marls and marly limestones in Malm alpha and gamma and predominantly limestones in Malm beta and delta/epsilon. Within the younger Malm zeta, a diversification of the sedimentary environment took place (Meyer and Schmidt-Kaler 1989). During the latest Jurassic and earliest Cretaceous, sedimentation changed to a brackish or hypersaline 'Purbeck' facies. Since these units are both carbonatic and cannot be separated in the seismic data, the latter is considered as a part of the Malm reservoir (Lemcke 1988).

Regarding the lithofacies of the Malm, two types of hyper-facies are distinguished: The so-called 'bedded facies' with typically thin-bedded marly or micrits limestones and the so-called 'mass facies' with thick-bedded limestone or dolomitic units and reef structures. Boehm et al. (2012) pointed out that in the Munich region, good reservoir properties can be expected from dolomitized limestones in the mass facies of the Malm zeta and in the Malm delta/epsilon due to parts having a favorable matrix porosity. In addition, the massy dolomitized limestones tend to have karstification potential (Stier and Prestel 1991) and also show a higher fracture density under structural impact due to more brittle properties.

Structurally speaking, the Bavarian Molasse Basin has undergone different tectonic stages of compressive and extensive regimes (Ziegler 1987). The tectonic map at the base Tertiary published in the geothermal atlas (2010) shows a dominant WSW-ENE system in the Munich area (Figure 1b). It consists mainly of antithetic normal fault systems with displacements of up to $150 \mathrm{~m}$, which are oriented parallel to the Alpine Orogen due to basin subsidence as well as subduction in the south (Bachmann et al. 1987). During the Upper Miocene, the compressive regime started with thrust faulting 
forming the folded Molasse with still a high pore pressure declining into the unfolded northern foreland (Mueller et al. 1988).

It is still being discussed where and to what an extent the younger alpine tectonics affects the unfolded foreland, since fracture porosity can be influenced significantly by the activity of faults. Previous publications of Betz and Wendt (1983) and Illies et al. (1981) presented conjugated lineament sets from satellite imagery in the western part and Unger (1999) described a set of strike-slip faults in the eastern part of the Bavarian Molasse Basin. Kraemer (2009) identified strike-slip faults in the SW of Munich close to the Alpine forefront. Megies and Wassermann (2014) analyzed recent seismic activity and concluded a NW-oriented strike-slip movement who identified a $\mathrm{N} 20^{\circ}$ to $45^{\circ} \mathrm{E}$ fault system from 3D seismic measurements (Lueschen et al. 2014).

The present-day maximum horizontal stress orientation in the Bavarian Molasse Basin is roughly perpendicular to the strike of the Alpine front, indicating that the first-order, far field tectonics in Western Europe is less dominant in the area than the second- and third-order stress pattern (Tingay et al. 2006). A regional study of the stress field in the Bavarian Molasse Basin based on breakout analysis by Reinecker et al. (2010) revealed a rather homogeneously distributed N-S-oriented stress with a dominating strike-slip or thrust faulting stress regime.

For the WSW-ENE-oriented fault systems, a limited reactivation potential can be assumed. The hydraulic potential of these faults probably is also limited. Consequently, faults related to a strike-slip regime as identified by the analysis of focal mechanisms of seismic events (Megies and Wassermann 2014) would also be of importance to geothermal exploration.

\section{Methods}

\section{Determination of the local stress field}

The stress field can be divided into first-order stresses as a result of forces generated at plate boundaries by e.g. global lithospheric motion and second-order stresses resulting from lithospheric flexure e.g. due to glacial loading and unloading or lateral density contrasts (Zoback 1992). On a local scale, third-order stresses in sedimentary basins are controlled by geological structures (Bell 1996a). On the reservoir scale, active faults, lateral or vertical contrasts in material parameters (for example, salt structures, decoupling horizons) can lead to mechanically modified parameters and deviations of the stress orientation and tectonic regime from the regional or plate-wide stress pattern (Tingay et al. 2006).

According to Anderson (1951), three tectonic regimes can be distinguished based on the magnitudes of the vertical stress $\left(\mathrm{S}_{\mathrm{v}}\right)$, the maximum horizontal stress $\left(\mathrm{S}_{\mathrm{H}}\right)$, and the minimum horizontal stress $\left(S_{h}\right)$. In a normal faulting regime $(N F), S_{v}$ is the maximum principle stress $\left(S_{1}\right)$. It is the intermediate principle stress $\left(S_{2}\right)$ in a strike-slip regime (SS) and the minimal principal stress $\left(\mathrm{S}_{3}\right)$ in a thrust faulting regime (TF). In regions with little topography, it is common to assume $\mathrm{S}_{\mathrm{v}}$ to be a principal stress.

In areas where no data of the stress magnitude are available, a method known as frictional equilibrium theory can be applied to reduce the range of possible stress ratios (Sibson 1974). Differential stress $\left(S_{1}-S_{3}\right)$ magnitudes in the brittle crust are limited by the frictional strength of optimally oriented faults (Jaeger et al. 2007). Byerlee (1978) has shown in laboratory tests that the coefficient of static friction $(\mu)$ is independent of 
the rock type but depends on the magnitude of normal stress. Accordingly, for normal stress bigger than $200 \mathrm{MPa}$, the coefficient of static friction of $\mu=0.6$ fits best and for lower normal stress $\mu=0.85$ can be applied. On the basis of the frictional equilibrium theory, stress polygons for frictionally stable areas in different stress regimes and possible horizontal stresses $\left(\mathrm{S}_{\mathrm{H}}\right.$ and $\mathrm{S}_{\mathrm{h}}$ ) can be defined (Zoback et al. 2003). In Figure 2a, the stress polygon for both static friction coefficients $(\mu=0.6$ and $\mu=0.85)$ is shown.

The determination of the stress components requires a number of theoretical considerations and a reliable data assessment. The $S_{\mathrm{v}}$ component can be estimated from the density of the overburden. Pore pressure $\left(\mathrm{P}_{\mathrm{p}}\right)$ can be estimated by hydraulic pumping tests or pressure measurements in the wells, and $S_{h}$ can be estimated from the vertical stress by making certain assumptions (e.g. no lateral strain), if measurements, such as mini-fractures or leak-off tests, are not available (Hubbert and Willis 1972; Zoback 2007). If FIT or cementation reports are available, it is also possible to calculate a minimal value for the least principal stress, which helps to define a lower limit of the stress gradient (Zoback et al. 2003).

In this study, stress-induced phenomena, such as DITF, DENF, and BO recorded at the borehole wall by both FMI and 6-arm caliper logs, were used. The stress state in a borehole with its circumferential/tangential $\left(\sigma_{\theta \theta}\right)$ and radial stress $\left(\sigma_{\mathrm{rr}}\right)$ components are described by Kirsch (1898) for a vertical well. For inclined wells, further computations with an analytical solution for the stress distribution are needed (Hiramatu and Oka 1968). According to these computations, the orientation of BO and DITFs does not only vary with the stress magnitudes but also with the orientation of the borehole trajectory relative to the stress tensor (Mastin 1988). Peska and Zoback (1995) described a method to determine the direction of the maximal $\left(\sigma_{\mathrm{tmax}}\right)$ and minimal tangential

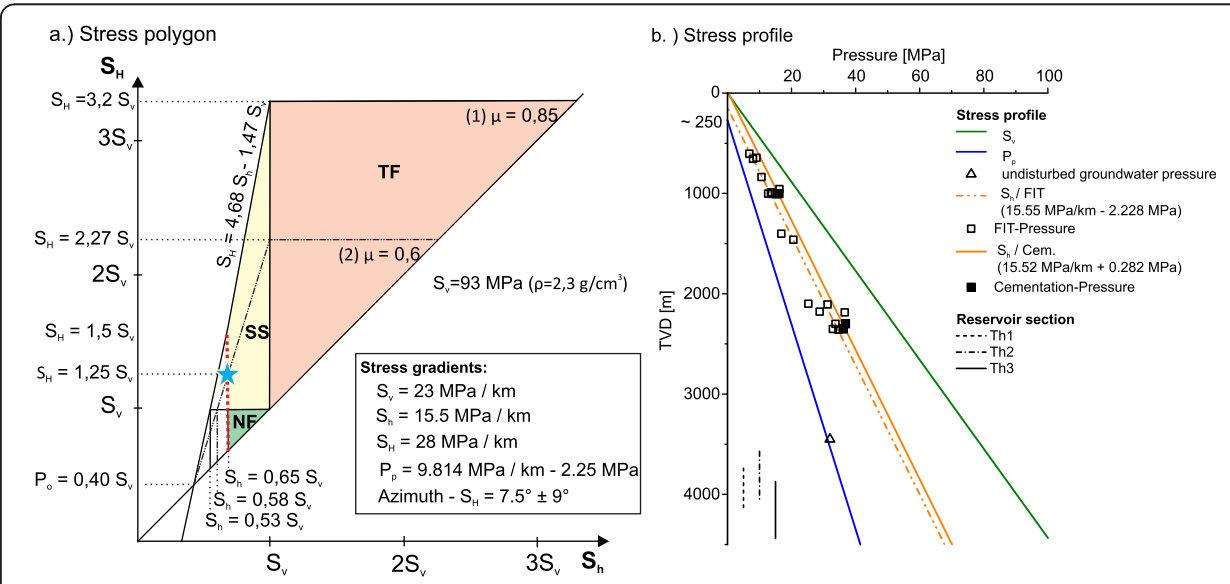

Figure 2 Stress field investigations. a). Stress polygon for a reservoir depth of 4,000 m TVD. Different stress regimes are illustrated (NF normal faulting (green), SS strike-slip faulting (yellow), TF thrust faulting (red)) with differential stress ratios (Anderson 1951) for $\mu=0.85$ (solid line) and (Bachmann et al. 1987) for $\mu=0.6$ (dotted line). The red dotted line describes the lower threshold for $S_{h}$ as obtained from FIT and cementation pressure data. The blue asterisk shows the stress tensor combining both stress polygons for $\mu=0.6$ as well as $\mu=0.85$ and the $S_{h}$ values resulting from FIT and cementation pressures. $\left.\mathbf{b}\right)$. Stress profiles: pore pressure $\left(P_{p}\right)$ for a groundwater level of $225 \mathrm{~m}$ and a pressure measurement at 3,450 m TVD result in a gradient of $9.814 \mathrm{MPa} / \mathrm{km}$ to $2.25 \mathrm{MPa}$; vertical stress $\left(\mathrm{S}_{\mathrm{v}}\right)$ for a mean density of the overburden of $2.3 \mathrm{~g} / \mathrm{cm}^{3}$; minimal horizontal stress $\left(S_{h}\right)$ gradients for the FIT data in the greater Munich area $\left(S_{h} / F I T\right)$ and minimal horizontal stress gradient from cementation pressures at the Sauerlach wells $\left(S_{h} / C e m\right.$.); reservoir sections for Th1, Th2, and Th3 (black dotted and solid lines). 
stresses $\left(\sigma_{\text {tmin }}\right)$ in deviated boreholes for effective stresses $\left(\mathrm{S}_{\mathrm{s}}=\mathrm{S}-\mathrm{P}_{\mathrm{p}}\right)$. It consists in a transformation of the principal stress tensor $\left(\mathrm{S}_{\mathrm{s}}\right)$ into the stress tensor in the geographic coordinate system $\left(\mathrm{S}_{\mathrm{g}}\right)$ using the transformation matrix $\mathrm{R}_{\mathrm{s}}$. Then, $\mathrm{S}_{\mathrm{g}}$ is transformed into the cylindrical borehole coordinate system $\left(\mathrm{S}_{\mathrm{b}}\right)$ by $\mathrm{R}_{\mathrm{b}}$. The complete transformation from principal $\left(\mathrm{S}_{\mathrm{s}}\right)$ to geographic $\left(\mathrm{S}_{\mathrm{g}}\right)$ and to the borehole coordinates $\left(\mathrm{S}_{\mathrm{b}}\right)$ is:

$$
S_{b}=R_{b} R_{s}^{T} S_{s} R_{s} R_{b}^{T}
$$

The stress state in the cylindrical borehole coordinate system $\left(\mathrm{S}_{\mathrm{b}}\right)$ is referred to an angle $\theta$, which is rotated in clockwise direction from the bottom of hole $(\mathrm{BOH})$ or top of hole (TOH) along the borehole axis, respectively. The following equations describe the cylindrical stress defined by Peska and Zoback (1995). Note the correction required for the Poisson's ratio $(v)$ and the pressure difference $(\Delta \mathrm{P})$ between mud pressure and $\mathrm{P}_{\mathrm{p}}$ (Zoback 2007):

$$
\begin{aligned}
& \sigma_{z z}=\sigma_{33}-2 v\left(\sigma_{11}-\sigma_{22}\right) \cos 2 \theta-4 v \sigma_{12} \sin 2 \theta \\
& \sigma_{\theta \theta}=\sigma_{11}+\sigma_{22}-2\left(\sigma_{11}-\sigma_{22}\right) \cos 2 \theta-4 \sigma_{12} \sin 2 \theta-\Delta P \\
& \sigma_{\theta z}=2\left(\sigma_{23} \cos \theta-\sigma_{13} \sin \theta\right) \\
& \sigma_{r r}=\Delta P
\end{aligned}
$$

where $\sigma_{\mathrm{zz}}$ is the stress in axial direction, $\sigma_{\theta \theta}$ the stress tangential to the borehole, and $\sigma_{\theta \mathrm{z}}$ represents the shear stress. The maximum $\left(\sigma_{\mathrm{tmax}}\right)$ and minimum tangential stresses $\left(\sigma_{\text {tmin }}\right)$ are defined by:

$$
\begin{aligned}
& \sigma_{\mathrm{tmax}}=\frac{1}{2}\left(\sigma_{z z}+\sigma_{\theta \theta}+\sqrt{\left(\sigma_{z z}-\sigma_{\theta \theta}\right)^{2}+4 \sigma_{\theta z}^{2}}\right) \\
& \sigma_{\text {tmin }}=\frac{1}{2}\left(\sigma_{z z}+\sigma_{\theta \theta}-\sqrt{\left(\sigma_{z z}-\sigma_{\theta \theta}\right)^{2}+4 \sigma_{\theta z}^{2}}\right)
\end{aligned}
$$

In order to determine the angles of $\sigma_{\mathrm{tmax}}$ and $\sigma_{\mathrm{tmin}}, \theta$ is varied in $0.2^{\circ}$ steps from $0^{\circ}$ to $360^{\circ}$. This enables us to determine the direction of the maximum of $\sigma_{\operatorname{tmax}}\left(\theta_{\text {maxmodel }}\right)$ and the minimum of $\sigma_{\text {tmin }}\left(\theta_{\text {minmodel }}\right)$. From this 'forward modeling', the compressive $\sigma_{\text {tmax }}$ as well as tensile stresses $\sigma_{\text {tmin }}$ and their orientations $\left(\theta_{\text {maxmodel }} / \theta_{\text {minmodel }}\right)$ are determined for a given well trajectory in an arbitrary stress field (see Chapter 4.2). For the Sauerlach well trajectories, the stress distributions are calculated for the well surface and compared to stress indicators like DITFs, DENFs, and BOs. This 'stress inversion' is applied in Chapter 4.3.

\section{Stress interpretation approach}

Information on the stress distribution in the Sauerlach project area was derived from oriented caliper measurements with EMS-GR-tools available for the $1^{\text {st }}, 2^{\text {nd }}$, and $3^{\text {rd }}$ sections of Sauerlach Th1 and from image measurements from FMI tools for all three wells of the reservoir section (see also Table 1). Oriented caliper logs measure mechanically the diameter of the borehole and link it with geographical information. The FMI tool measures the resistivity of the borehole wall in high resolution and display an oriented borehole resistivity wall image on this basis.

In image log data, natural fractures can be detected by their fracture resistivity contrasting to the surroundings and sinusoidal trace. Completely sinusoidal features with 
low resistivity (open fractures filled with mud) are distinguished from sinusoidal features, which only show a low resistivity in some areas (partly open fracture filled with mud), and sinusoidal features of higher resistivity than the formation (closed/healed fracture) (Trice 1999). Since the distribution of fracture orientation identified from the image log depends on the angle $\left(\mathrm{d}^{\circ}\right)$ between the fracture plane and the well trajectory, a bias correction for the fracture density, called 'Terzaghi correction', is applied (Terzaghi 1965). As a threshold for bias correction, it is used a value of $\mathrm{d}^{\circ}<15^{\circ}$.

$\mathrm{BO}$ occurs when $\sigma_{\mathrm{tmax}}$ exceeds the rock mass strength. They occur in the direction of maximum tangential stress $\left(\theta_{\max }\right)$ (Bell and Gough 1979). These structures can be detected by caliper or image logs or borehole televiewer tools. For the present study, the 'SAC' 6-arm caliper interpretation software was used (Wagner et al. 2004) and the criteria given by Reinecker et al. (2003) for 4-arm caliper tools were adapted to the 6-arm caliper tools. Averaging was performed using the circular statistics of Mardia (1972). BO analyses in image log data were described as blurry, conductive, symmetrical features (Figure 3a) by Bell (1996a).

During the process of drilling in highly fractured reservoirs, stress rearrangement at the borehole wall can enhance existing fractures in the direction of $\sigma_{\text {tmin }}\left(\theta_{\min }\right)$. Barton and Moos (2010) call these fractures drilling-enhanced natural fractures (DENFs). These structures are relatively short segments of fine-aperture natural fractures, which are not visible as complete sinusoidal traces (Figure 3c). DENFs are aligned to existing sinusoidal traces and can be fitted by flexible sinusoidal traces (Barton and Moos 2010). Due to the interaction of fracture planes and tensile stress, it is sometimes difficult to precisely determine the orientation of the tensile areas with DENFs. In comparison to DENFs, DITFs occur as axisymmetric pairs parallel to the borehole axis. They are formed when $\sigma_{\text {tmin }}$ reaches the tensile strength of the rock mass (Barton and Moos

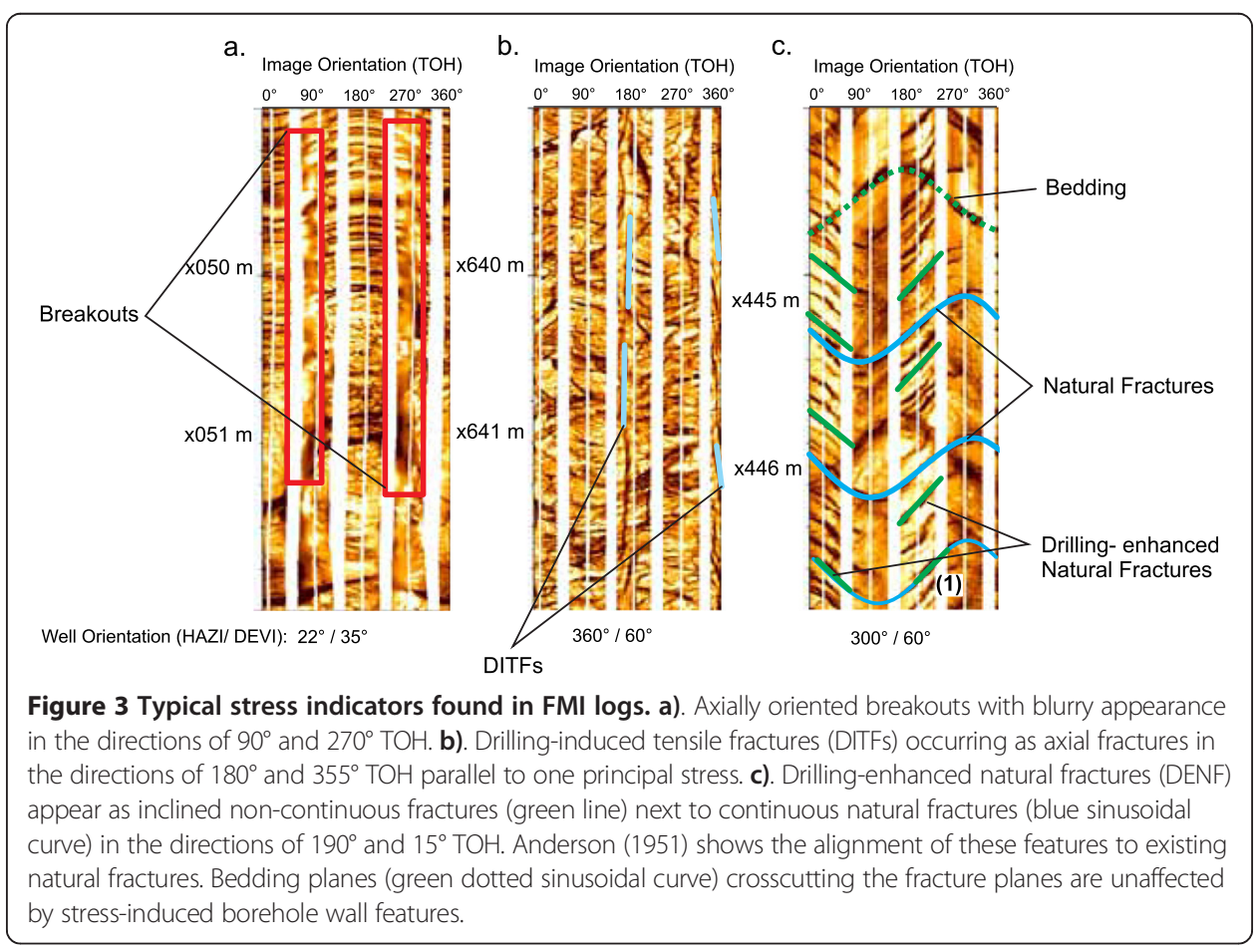


2010) and are promoted by cooling down the well or increasing the mud weight (Davatzes and Hickman 2010). For wells that are inclined to one principal stress axis, DITF occurs as en-echelon sets of fractures (E-DITFs) at a small angle to the borehole axis (Peska and Zoback 1995). Thus, axial fractures or E-DITF in combination with knowledge of the well trajectory indicate the principal stress direction. Petal-centerline fractures are features which develop during the drilling process in front of the drill bit in the plane of $\mathrm{S}_{\mathrm{H}}$ due to enhanced tensile stress. They can propagate into DITFs. The difference is that they develop as complex, non-planar features that typically are not coaxially oriented to the borehole (Davatzes and Hickman 2010). These features might be but not used in the dataset and can be responsible for data scattering of drillinginduced features.

In this study, we focus on DENFs and DITFs identified in the Sauerlach wells to analyze the orientation of $\sigma_{\mathrm{tmin}}\left(\theta_{\mathrm{min}}\right)$ and $\mathrm{BO}$ in order to determine the orientation of $\sigma_{\text {tmax }}\left(\theta_{\max }\right)$ in the borehole coordinate system. These data observed are finally compared to the modeled stresses as described above (Chapter 3.1) and discussed.

\section{Stress regime}

The orientation of the identified $\mathrm{BO}$ as derived from the interpretation of the 6-arm caliper measurements in Sauerlach Th1 is presented in Figure 4. From the top to $500 \mathrm{~m}$ TVD, numerous washout zones can be seen, which limit the interpretation and cannot be included in the results. From $500 \mathrm{~m}$ TVD to 2,600 m TVD, clearly identifiable $\mathrm{BO}$ zones exist. An inclination built-up beginning from 2,400 m TVD to more than $20^{\circ}$ from vertical, however, makes further $\mathrm{BO}$ interpretation due to severe tool decentralization impossible (Figure 4). The 220 BOs identified with a total length of

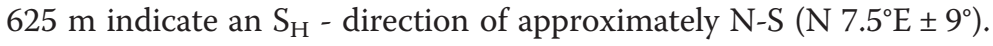

The section where image logs are acquired ranges from a depth of 3,700 to 4,100 m TVD. This open-hole section is highly deviated and covered by mainly Cenozoic compacted sand and clay stones. For this coverage, no density measurements were performed. Thus, for these sedimentary layers, we assume a mean density of 2,300 $\mathrm{kg} / \mathrm{m}^{3}$ (Fjaer et al. 2008). At reservoir level (4,000 m TVD), $\mathrm{S}_{\mathrm{v}}$ will be $92 \mathrm{MPa}$ with a stress gradient of $23 \mathrm{MPa} / \mathrm{km}$ (cf. Figure 2b). Due to low topography and investigations of focal mechanisms (Megies and Wassermann 2014), the vertical stress can be considered as a principal stress at the Sauerlach site.

Pore pressure measurements were conducted after drilling at 3,450 m TVD and reveal a static $\mathrm{P}_{\mathrm{p}}$ of $31.6 \mathrm{MPa} 550 \mathrm{~m}$ above the reservoir and a groundwater level of $225 \mathrm{~m}$ below surface. To extrapolate $\mathrm{P}_{\mathrm{p}}$ to reservoir depth (4,000 m TVD), a low mineralized model water with $\rho=1.000227 \mathrm{~g} / \mathrm{cm}^{3}\left(10^{\circ} \mathrm{C}, 1 \mathrm{bar}\right)$ is used. So the $\mathrm{P}_{\mathrm{p}}$ can be extrapolated to $37 \mathrm{MPa}\left(0.4 \mathrm{~S}_{\mathrm{v}}\right)$ at a depth of 4,000 $\mathrm{m}$ TVD, which results in a gradient of $9.814 \mathrm{MPa} / \mathrm{km}-2.25 \mathrm{MPa}$ (Figure $2 \mathrm{~b}$ ).

Technical drilling operations like FIT and cementation pressures from the Sauerlach drillings help to estimate the lower boundary of $S_{h}$ within the Molasse sediments. In Figure $2 \mathrm{~b}$, test pressures are illustrated as $S_{h} / F I T$ and $S_{h} / C e m$. They show a mean $S_{h}$ gradient of about $15.5 \mathrm{MPa} / \mathrm{km}$ (Figure $2 \mathrm{~b}$ ).

$\mathrm{S}_{\mathrm{H}}$ is determined by applying the stress polygon method (Zoback et al. 2003). For a given depth (here, we use the mean reservoir depth of 4,000 m TVD), the gradients of $\mathrm{S}_{\mathrm{v}}, \mathrm{P}_{\mathrm{p}}$ (introduced in the previous paragraphs), and the static friction coefficient $(\mu)$ give 

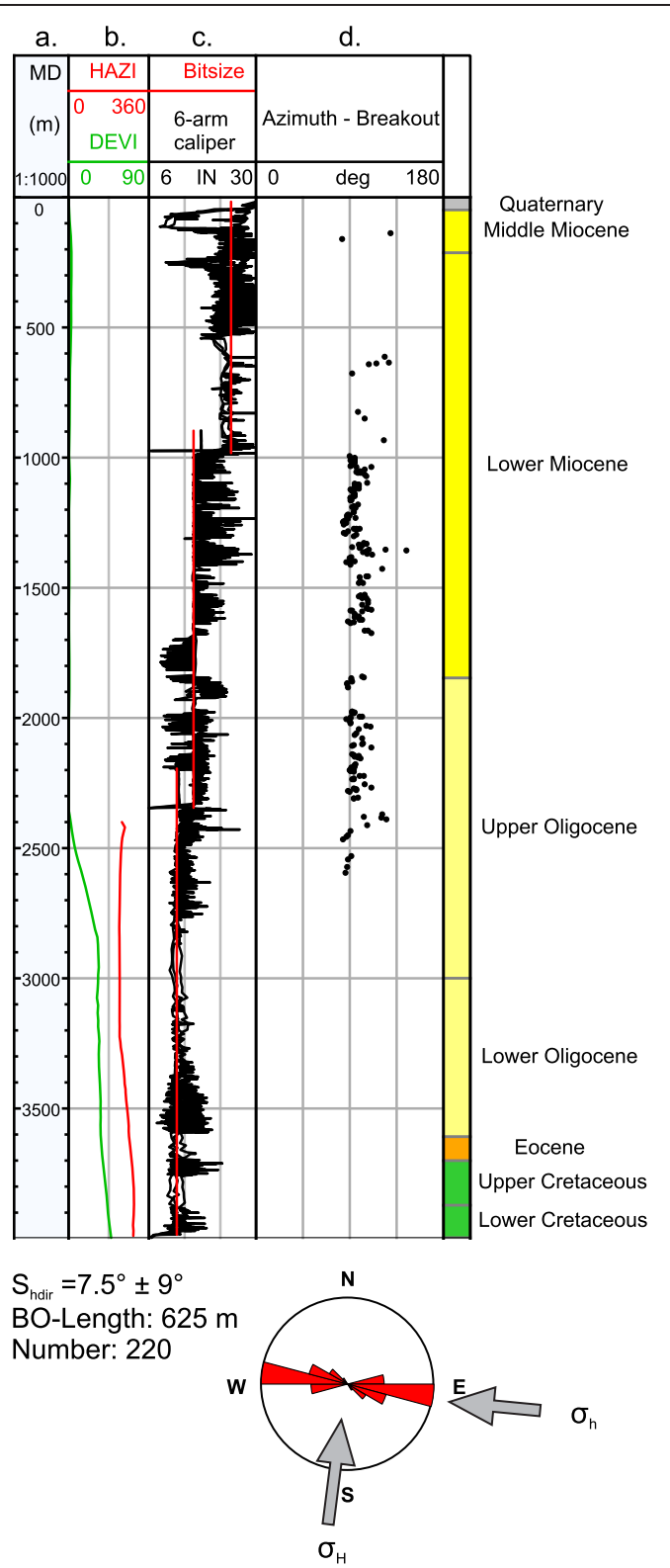

Figure 4 Breakout data measured by oriented 6-arm caliper tools in the $1 \mathrm{st}$, 2nd, and 3rd sections of well Th1. Column a). Well trajectory data: the 1st and 2nd sections are nearly vertical; in the 3rd section, well inclination is increased to $45^{\circ}$ with an azimuth of $230^{\circ}$ to $290^{\circ}$. Column b). Caliper diameter (black lines) and bitsize diameter (red line): the bitsize decreases from 23" in the 1st section to $16^{\prime \prime}$ in the 2 nd section and $12^{\prime \prime}$ in the 3 rd section. Column c). Breakout azimuth $\left(0^{\circ}\right.$ to $\left.180^{\circ}\right)$ determined with the 'SAC' software (Wagner et al. 2004): increasing well inclination at 2,700 m MD makes breakout interpretation impossible because of tool decentralization. Column d). Stratigraphic units: Upper Freshwater Molasse (OSM) at the middle Miocene to upper Lower Miocene $(50$ to $500 \mathrm{~m}$ ) is characterized by numbers of washouts; Upper Marine Molasse (UMM) at the middle Lower Miocene (500 to 800 m), good well stability and less breakouts are observed; Lower Freshwater Molasse (USM) at the middle Lower Miocene to the Lower Oligocene (800 to 2,800 m), clear breakout orientation, high number of breakouts.

the frictional limits for $S_{H}$ as well as $S_{h}$ for each stress regime (NF, SS, TF) (Figure 2a). According to Jaeger et al. (2007), the stress limits for optimally oriented faults can be described by the static friction coefficient, as it is exemplarily done for $\mu=0.6$ (lower static friction coefficient according to Byerlee). 


$$
\begin{aligned}
& \frac{S_{1}-P_{p}}{S_{3}-P_{p}}=\left[\left(\mu^{2}+1\right)^{1 / 2}+\mu\right]^{2} \quad \mathrm{P}_{\mathrm{p}}=0.4 \mathrm{~S}_{\mathrm{v}}, \mu=0.6 \\
& S_{1}+0.85 * S_{v}=3.12 * S_{3}
\end{aligned}
$$

For normal faulting $\left(\mathrm{S}_{\mathrm{v}}>\mathrm{S}_{\mathrm{H}}>\mathrm{S}_{\mathrm{h}}\right)$, strike-slip faulting $\left(\mathrm{S}_{\mathrm{H}}>\mathrm{S}_{\mathrm{v}}>\mathrm{S}_{\mathrm{h}}\right)$, and thrust faulting $\left(\mathrm{S}_{\mathrm{H}}>\mathrm{S}_{\mathrm{h}}>\mathrm{S}_{\mathrm{v}}\right)$, the limits can hence be defined as:

$$
\begin{array}{ll}
S_{h}=0.58 S_{v} & \left(S_{1}=S_{\mathrm{v}} ; S_{3}=S_{\mathrm{h}}\right) \\
S_{H}=3.12 S_{h}-0.85 S_{v} & \left(S_{1}=S_{H} ; S_{3}=S_{h}\right) \\
S_{H}=2.27 S_{v} & \left(S_{1}=S_{H} ; S_{3}=S_{v}\right)
\end{array}
$$

In Figure 2a, the stress polygon for a static friction coefficient of 0.6 (black dotted line) and for a static friction coefficient of 0.85 (black solid line) is illustrated. This method defines values for $S_{\mathrm{h}}\left(0.52 \mathrm{~S}_{\mathrm{v}}\right.$ for $\mu=0.85 ; 0.58 \mathrm{~S}_{\mathrm{v}}$ for $\left.\mu=0.6\right)$ which are smaller than the values measured with FIT and cementation pressures $\left(0.65 \mathrm{~S}_{\mathrm{v}}\right.$ ) (red dotted line). Using $\mu=0.85$, the stress polygon shows higher possible magnitudes of $\mathrm{S}_{\mathrm{H}}$, if $\mu=0.6$ lower values of $S_{H}$ are obtained for the same $S_{h} / S_{V}$. For the $S_{h}$ magnitude analyzed based on FIT and cementation reports $\left(\mathrm{S}_{\mathrm{h}}=0.65 \mathrm{~S}_{\mathrm{v}}\right), \mathrm{S}_{\mathrm{H}}$ magnitudes between $1.25 \mathrm{~S}_{\mathrm{v}}$ (for $\mu=0.6$ ) and $1.5 \mathrm{~S}_{\mathrm{v}}$ (for $\mu=0.85$ ) are obtained. Several authors give insights into the stress regime in the Bavarian Molasse Basin and describe it as being dominated by strike slip or thrust faulting (Illies et al. 1981; Reinecker et al. 2010), whereas local stress anomalies/perturbations (see Riem Th2 in Reinecker et al. (2010)) indicate similar magnitudes of $\mathrm{S}_{\mathrm{H}}$ and $\mathrm{S}_{\mathrm{h}}$.

For the following analyses, the stress regime is defined at the intersection point of the lower boundary of $S_{h}$ and the stress polygon for $\mu=0.6$ (blue asterisk in Figure 2a). The stress gradient for $S_{h}$ is $15.5 \mathrm{MPa} / \mathrm{km}$, for $S_{\mathrm{v}} 23 \mathrm{MPa} / \mathrm{km}$, and for $S_{\mathrm{H}} 28 \mathrm{MPa} / \mathrm{km}$. With regard to the stress orientation, $\mathrm{BO}$ data confirm the pervasive N-S orientation of $\mathrm{S}_{\mathrm{H}}$ (Reinecker et al. 2010).

\section{Identified natural fractures and drilling-induced stress indicators}

For the natural fractures analyzed according to the methods described in Chapter 3.2, a Terzaghi correction was applied. The Rose diagrams of the fracture orientations are illustrated in Figure 5 and statistical data presented in Table 2. The results of Sauerlach Th2 and Th3 show a bi-directional distribution in a main fracture set directed towards the ENE-WSW and a secondary orientation towards the N-S to NNE-SSW. In contrast to this, Sauerlach Th1 shows a singular natural fracture set directed N-S to NNE-SSW. Both fracture sets are inclined by $70^{\circ}$ to $90^{\circ}$. In Sauerlach Th1 oriented to N $300^{\circ} \mathrm{E}$ (see Figure 5a black arrow), the N-S fracture set exhibits an angle of $\mathrm{d}^{\circ}=60^{\circ}$ and the ENEWSW fracture set has an angle of $\mathrm{d}^{\circ}=30^{\circ}$. Therefore, the bias correction could be applied. In Sauerlach Th2 and Th3 oriented to $\mathrm{N} 0^{\circ} \mathrm{E}$ and to $\mathrm{N} 160^{\circ} \mathrm{E}$ (see Figure 5b, and c black arrow), by contrast, the angle of the NNE-SSW fracture set is $d^{\circ}=0^{\circ}$ to $15^{\circ}$, while that of the ENE-WSW fracture set is $\mathrm{d}^{\circ}=80^{\circ}$. In these wells, bias correction can be applied for the ENE-WSW fracture set but due to $\mathrm{d}^{\circ}$ values below the critical limit of $15^{\circ}$, this correction cannot be applied to the NNE-SSW fracture set. 
a.) Sauerlach Th1

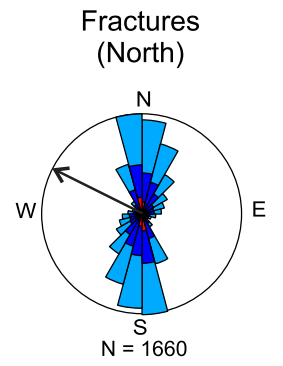

b.) Sauerlach Th2

Fractures

(North)

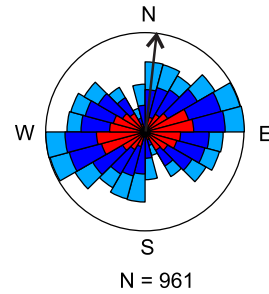

C.) Sauerlach Th3

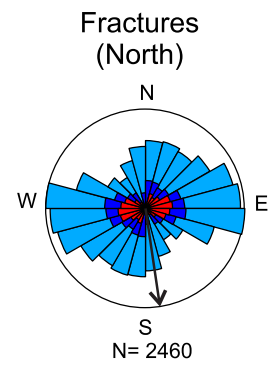

Fractures

$\mathrm{N}=2460$

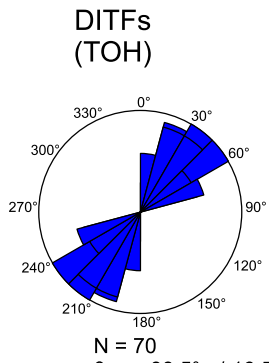

$\theta_{\mathrm{t} \min }=38.5^{\circ}+/-16.5^{\circ}$

\section{DITFs}

(TOH)

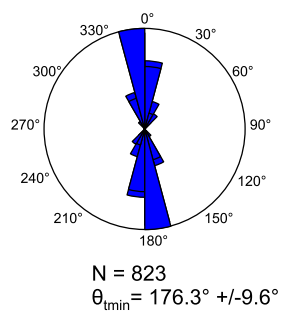

$\theta_{\mathrm{tmin}}=176.3^{\circ}+/-9.6^{\circ}$

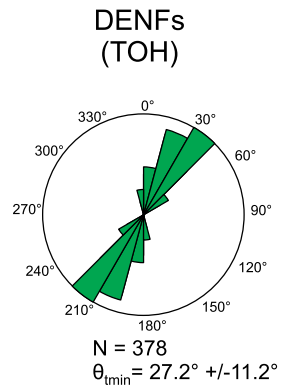

DENFs

$(\mathrm{TOH})$

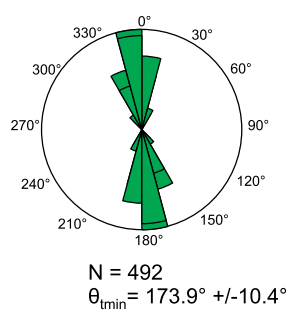

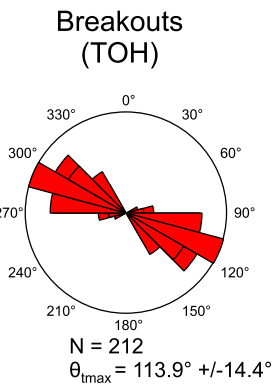

Breakouts (TOH)

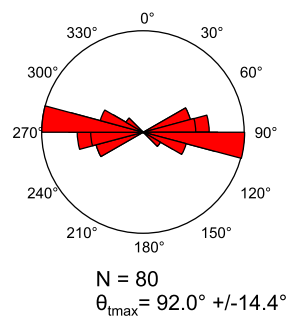

Breakouts (TOH)
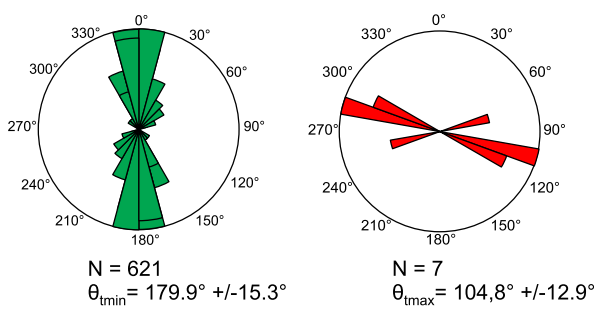

Figure 5 Data obtained from interpreting the FMI logs of Sauerlach Th1 (a), Th2 (b), and Th3 (c).

First column: Rose display of the Terzaghi-corrected fractures related to the geographic coordinate system. Light blue colors indicate partly conductive/partly open fractures, dark blue colors conductive/open fractures, and red colors resistive/healed fractures (Trice 1999). The black arrow indicates the mean well orientation in the logged interval and $N$ the total number of fractures. Second column: Drilling-induced tensile fractures (DITF) in the borehole coordinate system relative to the top of hole (TOH). $N$ indicates the number and $\theta$ the mean orientation with standard deviation. Third column: Drilling-enhanced natural fractures (DENF). Fourth column: Breakout (BO) data. All stress indicator data are measured in the borehole coordinate system against TOH due to high well inclination in the reservoir sections.

It has to be mentioned here that fracture interpretation in Sauerlach Th1 is of limited quality between 4,000 $\mathrm{m}$ and 4,390 $\mathrm{m} \mathrm{MD}$ due to extensive intersection of different fracture orientations, which is called crossfracturing (Figure 6a). This implies a partly low fracture density, although a highly fractured or deformed reservoir can be observed in the image log. In the transition zone of the alternating strata of dolomite and limestone to a compact limestone in the mass facies (4,350 m MD), the fracture density increases and cross-fracturing disappears. Such a change in fracture density is frequently observed in the Malm section of geothermal wells. This is also observed in Sauerlach Th2 and Th3 in the transition area to the compact deep dolomite units in the mass facies (4,600 m MD - Sauerlach Th2; 5,000 m MD - Sauerlach Th3). 
Table 2 FMI interpretation data from the Sauerlach Th1, Th2, and Th3

\begin{tabular}{lcccc}
\hline & & Sauerlach Th1 & Sauerlach Th2 & Sauerlach Th3 \\
\hline Logged length $(\mathrm{m})$ & & 776 & 825 & 1,147 \\
Fractures & Number & 1,660 & 961 & 2,460 \\
\multirow{2}{*}{ DITF } & Orientation (north) & N-S, NNE-SSW & ENE-WSW; NNE-SSW & ENE-WSW; NNE-SSW \\
& Number & 70 & 823 & 158 \\
& Total length (m) & 21 & 207 & 61 \\
RENF & Orientation (TOH) & $38.5^{\circ} \pm 16.5^{\circ}$ & $176.3^{\circ} \pm 9.6^{\circ}$ & $1.52^{\circ} \pm 15.7^{\circ}$ \\
& Number & 378 & 492 & 621 \\
& Total length (m) & 66 & 105.5 & 130 \\
BO & Orientation (TOH) & $27.2^{\circ} \pm 11.2^{\circ}$ & $173.9^{\circ} \pm 10.4^{\circ}$ & $179.9^{\circ} \pm 15.3^{\circ}$ \\
& Number & 212 & 80 & 7 \\
& Total length (m) & 95 & 24 & 2.6 \\
\hline
\end{tabular}

Logged length describes the reservoir depth where the image log is measured. The number and orientation for picked fractures, as well as the number, total length, and orientation for drilling-induced fractures (DITF), reopen natural fractures (RENF), and breakouts (BO), are measured.

BO indicating drilling-induced stress occurs in Sauerlach Th1 with a mean azimuth of $115^{\circ} \pm 14^{\circ}$ to $\mathrm{TOH}$ in the upper part of the reservoir between $4,050 \mathrm{~m}$ and $4,390 \mathrm{~m}$ MD depth, where crossfracturing dominates (Figure 6). Deeper than 4,390 m MD, the drilling process leads to a reactivation of intense fracturing and DENF occur with a direction of $27^{\circ} \pm 11^{\circ} \mathrm{TOH}$ (Figure 5a). In Sauerlach Th2 the direction of DITFs and DENFs is $176^{\circ} \pm 9.6^{\circ} \mathrm{TOH} / 173.9^{\circ} \pm 10.4^{\circ}$. Additionally, BOs can be found in a short area between 4,020 $\mathrm{m}$ and 4,140 $\mathrm{m} \mathrm{MD}$ with an orientation of $95^{\circ} \pm 14 \mathrm{TOH}$ (Figure 6). In Sauerlach Th3 mainly DENFs occur over the whole reservoir interval with an orientation of $179.9^{\circ} \pm 15.3^{\circ} \mathrm{TOH}$ (Figure 6).

\section{Interpretation and discussion of results}

\section{Fracture system and tectonic environment}

Fractures connected to normal faults form networks which are often subparallel to fault zones, resulting in a WSW-ENE-oriented fracture set in the Molasse Basin. Indeed, the fractures in the Sauerlach wells Th2 and Th3 show this orientation (Figure 5b/c). Sauerlach Th1, by contrast, is oriented between two terminating normal faults and shows a unimodal fracture set distribution between $\mathrm{N} 350^{\circ}$ and $10^{\circ} \mathrm{E}$ (Figure 5a), although fractures oriented towards the WSW-ENE would be partly affected by observation bias.

Near to fault zones fracture density frequently increases and rock mass strength is reduced. In general, fault zones possess a complex structure so that it is hard to identify them solely from borehole data. Additional indication of a fault may be found in the upper part of Sauerlach Th1 (4,000 to $4,390 \mathrm{~m} \mathrm{MD}$ ). It is dominated by crossfracturing which is difficult to identify, but shows a deformed rock mass. The lower part (4,390 $\mathrm{m}$ to $4,760 \mathrm{~m} \mathrm{MD})$ does not exhibit any deformation and only tension fractures occur. Typically, the Malm carbonates show a high rock mass strength reflected by a good well stability in Sauerlach Th2 and Th3 (Figure 6b/c), but cross-fracturing and the high breakout frequency between 4,000 $\mathrm{m}$ to 4,390 m MD in Sauerlach Th1 indicate cataclastic rocks and a reduced rock strength (Figure 6a). 


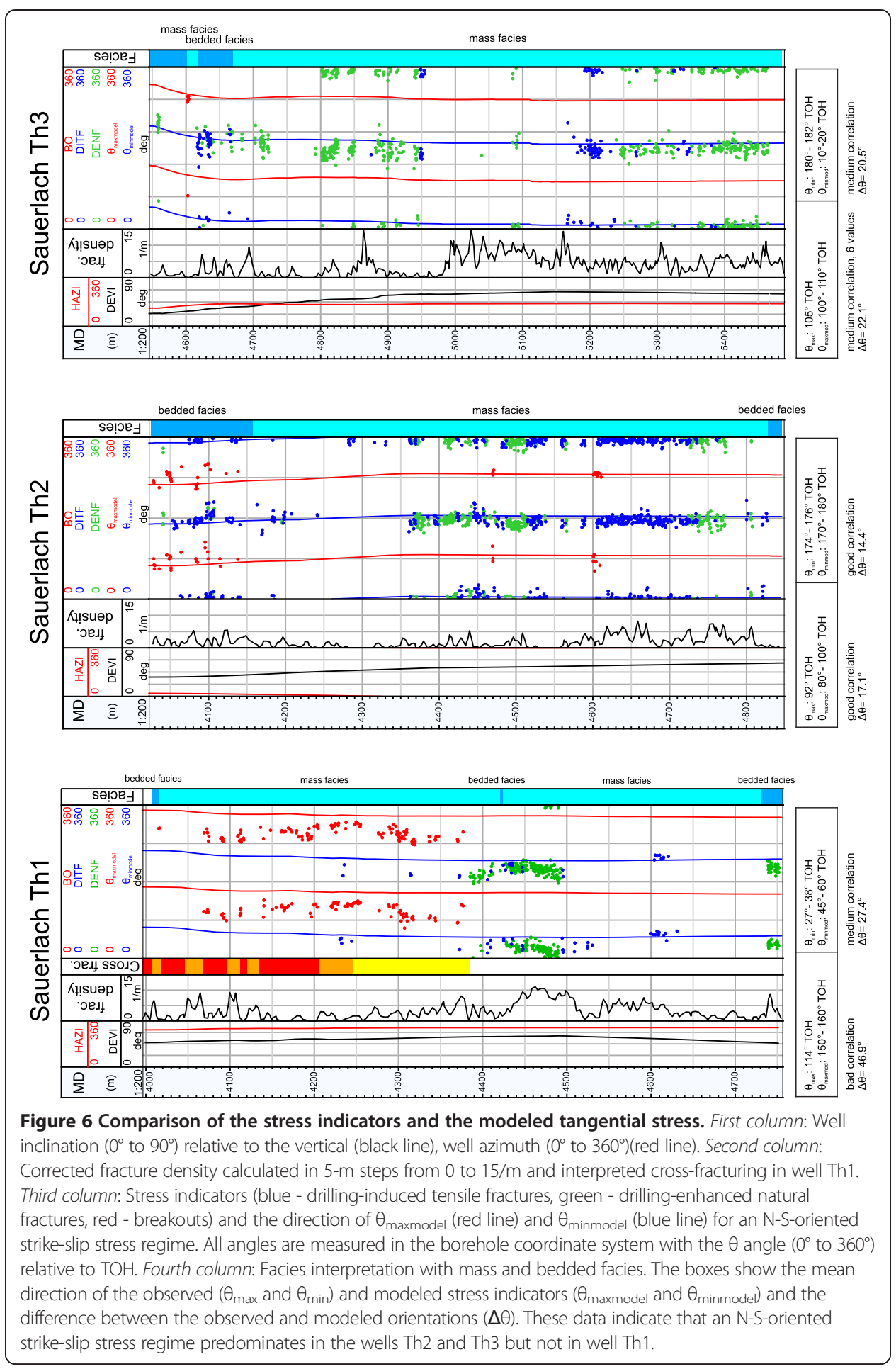

Since no further direct information on the structural setting around Sauerlach Th1, e.g. from 3D seismic data, is available, the fracture system as a single source of information could indicate an N-S-oriented fault zone. However, an N-S-oriented fault system has not yet been discussed for the Bavarian Molasse Basin. When considering strike-slip environments (Lueschen et al. 2014; Megies and Wassermann 2014) with faults oriented to 
$\mathrm{N} 20^{\circ}$ to $45^{\circ} \mathrm{E}$, however, such a fault system may exist, since fracture in strike-slip fault zones are not always oriented parallel to the fault zone (Sylvester 1988).

\section{Stress indicators and modeled stress directions}

The wellbore trajectory and the stress field control the state of stress at the wellbore wall and the occurrence of BOs, DENFs, and DITFs (see Chapter 3.2). The input stress magnitudes of our model approach are shown in Figure $2 \mathrm{~b}$ (see Chapter 3.3). Figure 6 presents the results of $\theta_{\text {minmodel }}$ (blue line) and $\theta_{\text {maxmodel }}$ (red line) with the picked BOs, DENFs, and DITFs.

Moreover, Figure 6a shows a mismatch between the orientation of observed features and those assuming a strike-slip regime. The mismatch differs in two distinct sections: (i) between 4,000 $\mathrm{m}$ and 4,380 $\mathrm{m} \mathrm{MD}$, there is a significant offset between $\theta_{\text {maxmodel }}$ and $\theta_{\max }$ of $35^{\circ}$ to $45^{\circ}$ (Figure 6/Sauerlach Th1) and (ii) between $4,380 \mathrm{~m}$ and $4,760 \mathrm{~m}$ MD the offset is shifted by a mean of $15^{\circ}$ to $30^{\circ}$ with respect to $\mathrm{TOH}$.

In contrast to this, the observed $\theta_{\max }$ from BOs and $\theta_{\min }$ from DENFs and DITF in Sauerlach Th2 correlate well with the modeled stress orientations and confirm the stress conditions assumed for modeling (Figure 6/Sauerlach Th2). The data set of Sauerlach Th2 is considered to be representative due to the low standard deviation and high number of stress indicators in the well interval (BO, DENF, and DITF). Modeled stress orientations in Sauerlach Th3 generally confirm the assumed stress regime with DITF and DENF (Figure 6/Sauerlach Th3); however, few BOs to localize $\theta_{\max }$ can be interpreted.

The observations made, in combination with modeling, suggest local stress changes in the vicinity of the wells. The wells oriented north (Sauerlach Th2) and south (Sauerlach Th3) exhibit a strike-slip stress regime with $\mathrm{S}_{\mathrm{H}}$ oriented N-S. The modeled stress distribution of Sauerlach Th1 oriented NW-SE differs. The mismatch between observed and modeled data requires a critical review of potentially influencing factors and will be discussed in the following sections.

\section{Sensitivity study of Sauerlach Th1 and Th2}

Heterogeneous structures, such as highly fractured zones or locally changed lithological composition in the reservoir, can have an influence on the local stress regime and stress trajectories (Bell 1996b; Homberg et al. 1997). Depending on the distance to the fault or its properties, the direction and the magnitude of the maximum horizontal stress can significantly vary in the vicinity of these structures (Shamir and Zoback 1992; Hickman and Zoback 2004).

The direction and the stress regime based on the stress indicators are investigated to identify the local stress field in the vicinity of the wells. The depth (TVD) and the well trajectory at the position of every stress indicator are included, and the angle $\theta_{\text {maxmodel }}$ as well as $\theta_{\text {minmodel }}$ (see Chapter 3.1) are calculated. For every stress regime, the average values of the square roots of the directional differences of the observed $\left(\theta_{\text {obs }}\right)$ vs. modeled stresses $\left(\theta_{\text {model }}\right)$ are calculated. For every stress regime, the mean directional difference $(\Delta \theta)$, including all stress indicators, is defined.

$$
\Delta \theta=\sqrt{\frac{\sum\left|\theta_{\text {obs }}-\theta_{\text {model }}\right|^{2}}{N}}
$$


This value can be used to better describe the validity of a stress model applied to stress indicators. First, the influence of the $S_{h}$ magnitude is studied by varying its magnitude. In a second step, the magnitude and the orientation of $\mathrm{S}_{\mathrm{H}}$ are varied and $S_{\mathrm{h}}$ is kept constant.

To study the influence of $S_{h}$, the magnitudes of $S_{H}$ and $S_{v}$ are kept constant in a strike-slip regime $\left(\mathrm{S}_{\mathrm{H}}=1.25 \mathrm{~S}_{\mathrm{v}}\right)$ (Figure $7 \mathrm{~b}$ ) and the magnitude of $\mathrm{S}_{\mathrm{h}}$ is varied from low values $\left(0.65 S_{\mathrm{v}}\right)$ to higher values $\left(\mathrm{S}_{\mathrm{v}}\right)$. In the same way, the influence of $\mathrm{S}_{\mathrm{h}}$ on stress distribution in a normal faulting regime is verified $\left(\mathrm{S}_{\mathrm{H}}=0.9 \mathrm{~S}_{\mathrm{v}} ; \mathrm{S}_{\mathrm{h}}<0.9 \mathrm{~S}_{\mathrm{v}}\right.$ ) (Figure 7a). Figure 7 illustrates the $\Delta \theta$ values for $S_{h} / S_{v}$ ratios at $\theta_{\max }$ and $\theta_{\text {min }}$. In a strike-slip regime, the standard deviations for different $S_{\mathrm{h}}$ values are between $0.8^{\circ}$ to $6^{\circ}$ (Figure $7 \mathrm{~b}$ ); in a normal faulting regime (Figure 7a), these values are between $0.5^{\circ}$ and $4^{\circ}$ and emphasize that the $S_{h}$ magnitude does not have a significant impact on stress distribution at the borehole wall. Thus, in the following consideration, $S_{h}$ will be kept constant to simplify the analyses.

In the next step, the influence of the $\mathrm{S}_{\mathrm{H}}$ direction as well as of the $\mathrm{S}_{\mathrm{H}}$ magnitude on $\Delta \theta$ values for compressive stress indicators is analyzed. Here, the focus lies on the wells Th1 and Th2 because of the large numbers of stress indicators. As illustrated in Figure $7, S_{h}$ has a small influence on $\Delta \theta$. It is concluded that it remains unaffected by stress perturbations and is kept constant at $0.65 \mathrm{~S}_{\mathrm{v}}$. The direction of $\mathrm{S}_{\mathrm{H}}$ is rotated clockwise from $\mathrm{N} 0^{\circ}$ to $180^{\circ} \mathrm{E}$ (north to south), and the stress regime is varied from a normal faulting regime with nearly isotropic horizontal stress $\left(\mathrm{S}_{\mathrm{H}}=0.7 \mathrm{~S}_{\mathrm{v}}\right)$ to a strike-slip faulting regime $\left(\mathrm{S}_{\mathrm{H}}=1.25 \mathrm{~S}_{\mathrm{v}}\right)$. This variation can be traced in the stress polygon from the blue asterisk to the lower limit of the red dotted line (Figure 2a).

a.) Normal faulting regime $\left(\mathrm{S}_{\mathrm{H}}=0.9 \mathrm{~S}_{\mathrm{v}}\right)$

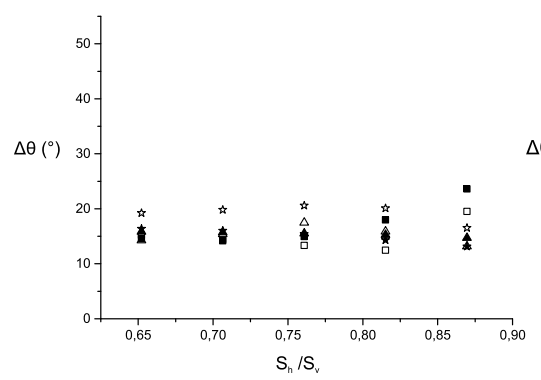

$\Delta \theta_{\text {min }}$

व $T h 1-14.9^{\circ}+1-2.7^{\circ}$

$\triangle$ Th2 $-15.2^{\circ}+1-1.6^{\circ}$

$\Delta \theta$

- Th1 $-17.1^{\circ}+/-4.0^{\circ}$

- Th1 $-17.1^{\circ}+/-4.0^{\circ}$ b.) Strike- slip regime $\left(\mathrm{S}_{\mathrm{H}}=1.25 \mathrm{~S}_{\mathrm{v}}\right)$

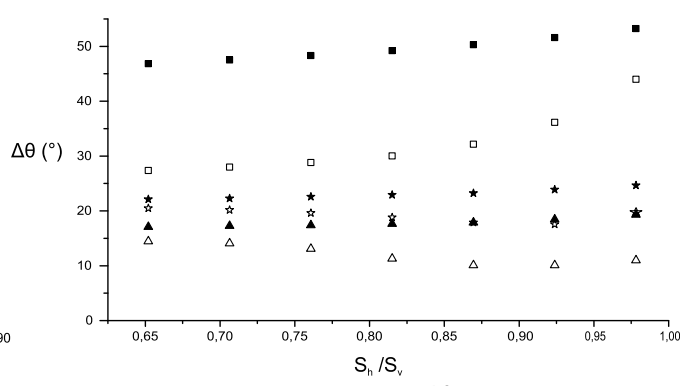

$\Delta \theta_{\text {min }}$

ㄷ $\operatorname{Th} 1-32.4^{\circ}+1-6.0^{\circ}$

$\Delta$ Th2 $-12.0^{\circ}+1-1.8^{\circ}$
$\Delta \theta_{\text {max }}$ Th1 $-49.6^{\circ}+1-2.3^{\circ}$ Th $2-17.8^{\circ}+1-0.8^{\circ}$

Figure 7 Mean difference between the modeled and observed stress orientations $(\Delta \theta)$ for varied minimal horizontal stresses. $\theta_{\min }$ from DITF and DENF as well as $\theta_{\max }$ from $\mathrm{BO}$ are compared to the modeled directions $\left(\theta_{\text {maxmodel, }} \theta_{\text {minmodel }}\right)$ in (a). a normal faulting $\left(S_{H}=0.9 S_{v}\right)$ and $(\mathbf{b})$. a strike-slip stress regime $\left(S_{H}=1.25 S_{v}\right)$ for a variable $S_{h}$ magnitude. The value of $\Delta \theta$ is calculated to evaluate the consistency of the model (see Chapter 4.3). The $S_{h} / S_{v}$ ratio's independence of the stress distribution results in constant $\Delta \theta$ values and low standard deviations. In the normal faulting regime (a)., the $\Delta \theta$ values for Th1, Th2, and Th3 are particularly constant for different $S_{h} / S_{v}$ ratios. Such constant $\Delta \theta$ values are also seen in the strike-slip regime (b). for Th2 and Th3. The data of Th1 in b.) illustrate a change for increasing $S_{h} / S_{v}$ ratios, but the standard deviation is even lower than $6^{\circ}$. These results show that the $S_{h} / S_{v}$ ratio does not have a significant impact in stress distribution in the well. So, further analyses will be based on fixed $S_{h} / S_{v}$ ratios with modified SH magnitude and SH orientation. 
Figure 8 shows the $\Delta \theta$ values for compressive stress indicators (BO) in Th1 and Th2 as a function of $\mathrm{S}_{\mathrm{H}}$ orientation and $\mathrm{S}_{\mathrm{H}}$ magnitude. White areas define stress regimes with $\Delta \theta$ values lower than $20^{\circ}$. Gray to black areas indicate high $\Delta \theta$ values of up to $70^{\circ}$. Consequently, the white areas represent stress regimes with the best agreement of observed and modeled data.

In Sauerlach Th1, the observations do not correlate with the assumed strike-slip stress regime which is marked by the blue asterisk for low values of $\Delta \theta$. The best fit is marked by the black line (Figure 8/Sauerlach Th1). A good fit between model and data is obtained for either a rotation of $40^{\circ}$ to a direction of $\mathrm{N} 150^{\circ} \mathrm{E}$ in a strike-slip regime $\left(S_{H}>S_{V}\right)$ (Figure 8/orange asterisk) or for unperturbed stress orientations $\left(\mathrm{S}_{\mathrm{Hdir}}=\mathrm{N} 10^{\circ} \mathrm{E}\right)$ by a reduction of $\mathrm{S}_{\mathrm{H}}$. The latter indicates a stress regime change to an intermediate strike-slip/normal faulting regime $\left(S_{H}=S_{v}\right)$ or a normal faulting regime with $\mathrm{S}_{\mathrm{H}}=0.85 \mathrm{~S}_{\mathrm{v}}$ (Figure 8/yellow asterisk).

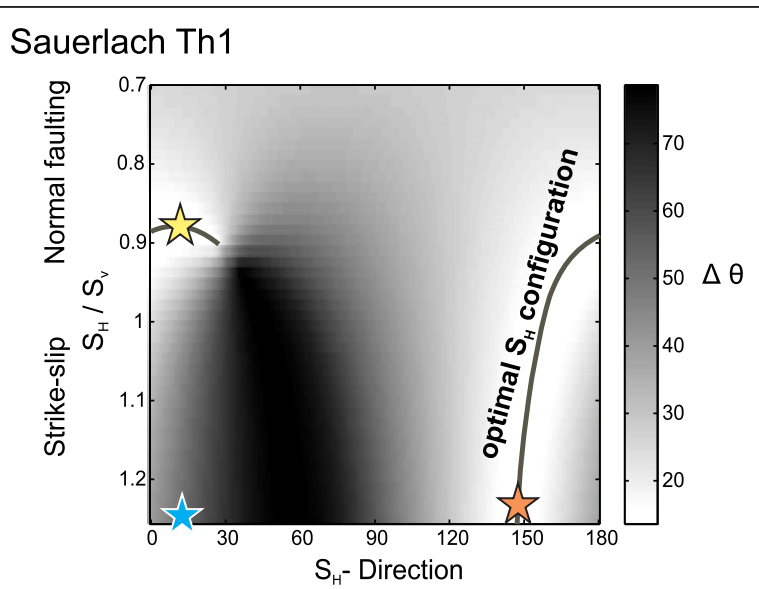

\section{Sauerlach Th2}

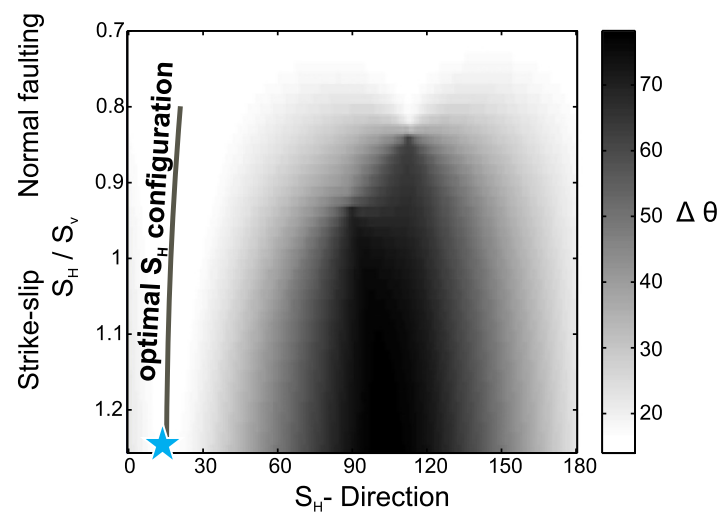

Figure 8 Differences of the modeled and observed stress indicators for a varied direction and stress regime. The vertical $\left(S_{v}\right)$ and the minimum horizontal stresses $\left(S_{h}\right)$ are kept constant $\left(0.65 S_{v}\right)$, and the stress direction and the magnitude of the maximum horizontal stress $\left(S_{H}\right)$ are changed ( $S_{H}$-dir: $0^{\circ}$ to $180^{\circ}, S_{H}: 0.7$ to $1.25 \mathrm{~S}_{\mathrm{v}}$ ). The location of the strike-slip stress tensor is shown by the blue asterisk. The colors illustrate the mean difference $(\Delta \theta)$ between the observed and modeled maximum tangential stresses. Th1 shows a rotation of the stress regime (orange asterisk), or a change in the stress regime to normal faulting (yellow asterisk) fits our observation best. In Th2, the N-S-oriented strike-slip regime is confirmed, but this analysis also suggests that stress direction is independent in a normal faulting regime. 
The best fit for well Sauerlach Th2 shows that without stress rotation $\left(\mathrm{S}_{\mathrm{Hdir}}=\mathrm{N} 10^{\circ} \mathrm{E}\right)$, the observed stress indicators can be modeled in a strike-slip regime $\left(1.25 \mathrm{~S}_{\mathrm{v}}>\mathrm{S}_{\mathrm{H}}>\mathrm{S}_{\mathrm{v}}\right)$, intermediate strike-slip/normal faulting regime $\left(S_{H}=S_{v}\right)$ or a normal faulting regime $\left(S_{\mathrm{v}}>\mathrm{S}_{\mathrm{H}}\right)$ (Figure 8/Sauerlach Th2). The line of best fit correlates well with the N-Soriented strike-slip stress regime marked by the blue asterisk in Figure 2. It is worth mentioning that in Sauerlach Th2 for $\mathrm{S}_{\mathrm{H}} / \mathrm{S}_{\mathrm{v}}<0.8$ (normal faulting regime), the results are independent of the $\mathrm{S}_{\mathrm{H}}$ orientation. Therefore, it is not possible to deduce a preferential stress orientation.

Stress modeling indicates that stress indicators observed in Sauerlach Th1 show the influence of local stress perturbations. Stress magnitude determination is based on the existence and the orientation of breakouts, but we did not use e.g. breakout depths and width in combination with strength to estimate the stress magnitude. For additional analyses, geomechanical data and logging information, such as acoustic logs, cored sections, and extended pressure tests, are required.

\section{Conceptual model at the Sauerlach site}

According to Illies et al. (1981) and Reinecker et al. (2010), the stress regime in the Bavarian Molasse Basin is primarily influenced by the alpine orogeny and oriented accordingly perpendicular to it (N-S to NW-SE). Breakout interpretation in the Sauerlach wells based on the caliper data in the Cenozoic sediments from 500 to 2,600 m TVD reveals a mean $S_{H}$ direction of $\mathrm{N} 7.5^{\circ} \mathrm{E} \pm 9^{\circ}$. The total breakout length $(625 \mathrm{~m})$ and total logged interval with breakout zones $(2,100 \mathrm{~m})$ give a ratio of 0.30 and indicate a mean differential stress for breakout formation. This phenomenon is interpreted by Illies et al. (1981) and Reinecker et al. (2010) to be an indicator of a strike-slip or thrust faulting regime and also the focal mechanisms analysis (Megies and Wassermann 2014) support this interpretation.

The number and total length of breakouts within the Cenozoic sedimentary layers in Sauerlach Th1 (Figure 4) is much higher than in the Malm reservoir in Sauerlach Th1, Th2, and Th3 (Table 2). This can be the result of lower tangential compressive stress due to the well trajectory, a changed stress regime or higher rock strength in the Malm reservoir. Nevertheless, the analysis of stress indicator orientation indicates an N-S-oriented stress field with a strike-slip character for the wells Sauerlach Th2 and Th3. According to our stress inversion, a transitional strike-slip/normal faulting $\left(S_{\mathrm{V}}=\mathrm{S}_{\mathrm{H}}\right)$ or a normal faulting regime $\left(\mathrm{S}_{\mathrm{H}}<\mathrm{S}_{\mathrm{V}}\right)$ might exist when judging from the stress data. We therefore conclude a strike-slip to normal faulting regime where the compressional character decreases with depth due to higher vertical stress gradients in comparison to the horizontal stress gradients. The absence of stress rotation with depth points to significantly different horizontal stress magnitudes as also observed by Reinecker et al. (2010).

Our stress inversion in Sauerlach Th1 indicates either a normal faulting regime $\left(S_{v}>S_{H}\right)$ with $\mathrm{S}_{\mathrm{H}}$ oriented to $\mathrm{N} 10^{\circ} \mathrm{E}$ or a rotation of $\mathrm{S}_{\mathrm{H}}$ oriented to $\mathrm{N} 150^{\circ} \mathrm{E}$ in a strike-slip stress regime $\left(S_{H}>S_{v}\right)$. Compared to the observations in Sauerlach Th2 and Th3, this would indicate a regionally perturbed stress field of 2 nd- or 3rd-order stress patterns. Such a perturbed stress field at the Sauerlach site is not a unique phenomenon in the Molasse Basin; according to Reinecker et al. (2010), at least ten wells indicate a locally rotated stress field. Within the geothermal reservoir in the Bavarian Molasse Basin, units with a perturbed stress field can either be linked to lithofacial homogeneous bodies 
(e.g. reef complexes) with a significant size or tectonic structures, as e.g. observed in a set of combined strike-slip/extensional fault system with several en-echelon normal faults building several small relay ramps (Lueschen et al. 2014). Consequently, wells drilled into the normal faults, such as Sauerlach Th2 and Th3, may exhibit a fracture set that differs significantly from that of Sauerlach Th1 which is drilled in-between two terminating normal faults.

The identified mainly N-S- to NNE-SSW-oriented fractures in Sauerlach Th1 are either influenced from a dilatational tendency in a normal faulting regime with an N-Soriented SH (Figure 9/white arrows in Case II) or a shearing character in the rotated strike-slip stress regime (Figure 9/shear movement in Case I). In both scenarios, the fractures would have an opening character and provide a good hydraulic activity. Therefore, the above-presented structural concept goes along with the observations during the early stage of pumping tests corresponding with a high negative skin effect indicating a good connectivity of Sauerlach Th1 to the reservoir (see Chapter 2.1). From this perspective, it is presumed that these open fractures contribute to the high productivity of the well by a low turbulent inflow into the borehole.

Compared to the fractures in Sauerlach Th2 and Th3 which are mainly oriented ENE-WSW, they are identified to be closing within the observed stress field. Therefore, it seems that these are unfavorable for geothermal targeting though a

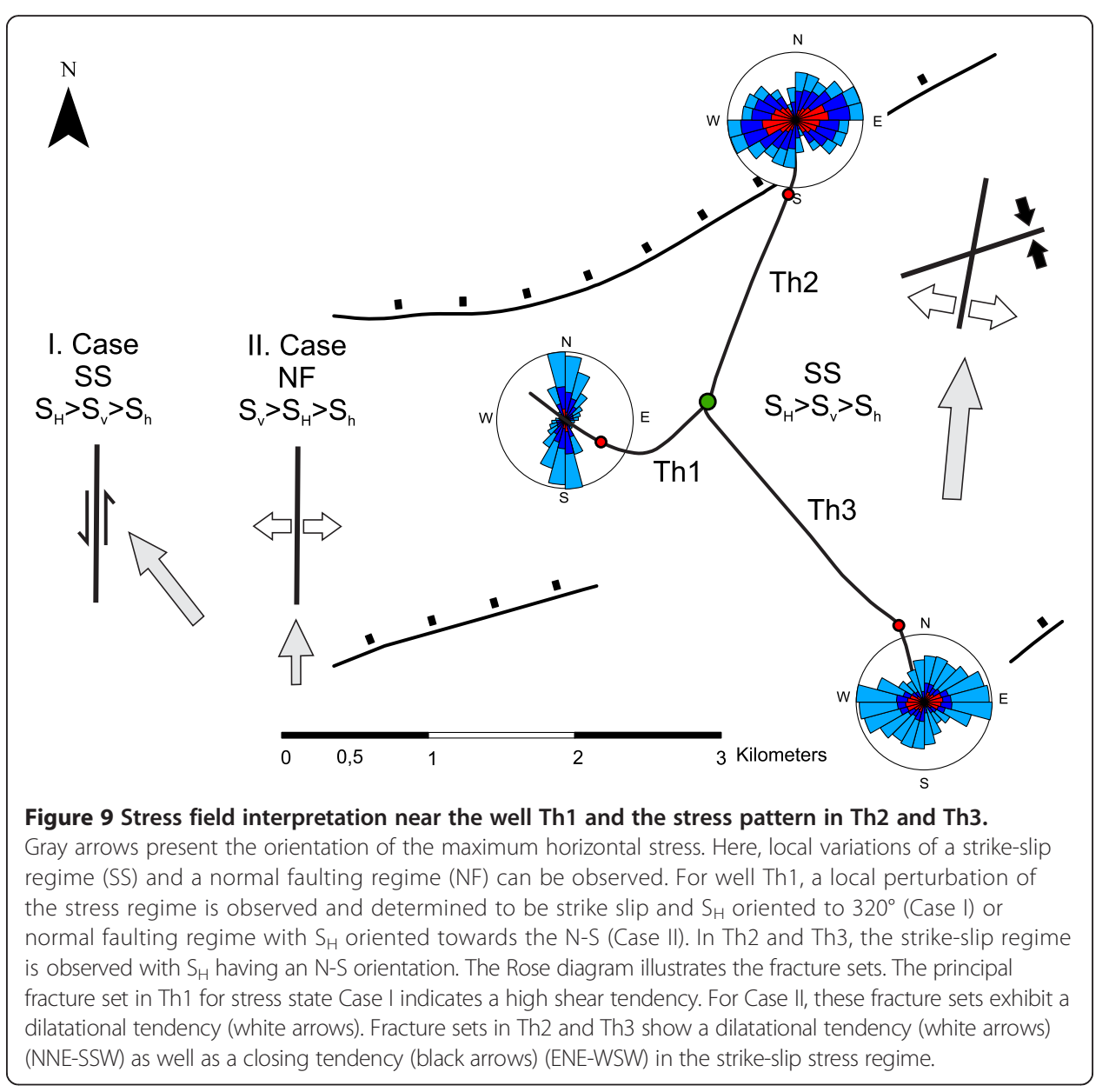


significant displacement along with faulting and was initially encountered in the seismic data.

\section{Conclusion}

The stress analysis made within the framework of this study has shown that the strike-slip stress regime with a N-S-oriented $\mathrm{S}_{\mathrm{H}}$ can be found in the Cenozoic layers in one well (Sauerlach Th1) and even in the Malm reservoir in two other wells (Sauerlach Th2 and Th3). Stress inversion of the breakout data measured in the Malm reservoir of Sauerlach Th1 and Th2 indicates a perturbed stress regime for Sauerlach Th1. The fracture systems within the Malm reservoir of Sauerlach Th2 and Th3, both drilled towards the WSWENE faults, have a predominant WSW-ENE orientation. In contrast, Sauerlach Th1, drilled between the northern and southern WSW-ENE fault zones, exhibits an N-S- to NNE-SSW-oriented fracture system. This tectonic situation can lead to consequences for the hydraulic system for both inferred stress regimes:

A) In a stress regime with nearly N-S-oriented $\mathrm{S}_{\mathrm{H}}$, the N-S- to NNE-SSW-oriented fracture system, which is dominant in the Sauerlach Th1 but very minor seen in Sauerlach Th2 and Th3, can have a dilatational character (Figure 9/white arrows in Case I).

B) In a $\mathrm{N} 150^{\circ} \mathrm{E}$-oriented strike-slip stress regime, the N-S- to NNE-SSW-oriented fracture planes will reach highest shear stress (Figure 9/shear movement in Case I) and most likely experience shear movement.

In both cases, the fracture aperture might be increased, leading to better hydraulic connectivity. This is supported by the fact that Th1 has a higher productivity. Overall, the identified stress effects help us to understand the hydraulic properties of the well Sauerlach Th1 compared to the wells Sauerlach Th2 and Th3. In this study, we could assess the stress distribution in highly deviated wells at the Sauerlach site. The approach chosen, however, is not site specific and can be transferred to other wells. The ability to identify and precisely locate stress perturbations can improve the predictability of hydraulic performance and thus contribute to a better assessment strategy.

Competing interests

The authors declare that they have no competing interests.

Authors' contributions

RS carried out the data analysis and modeling and wrote the manuscript. US and BM participated in analyzing the results and in drafting the manuscript. TK initiated the study and participated in the design, coordination, and quality control of the project and in drafting the manuscript. $\mathrm{CH}$ completed the data set and was involved in drafting the manuscript. All authors read and approved the final manuscript.

\section{Acknowledgements}

Grateful thank goes to the reviewers for their helpful expertice in improving the manuscript. We would like to thank the Stadtwerke München for the provision of the data set and the permission to publish the results. Special thanks go to Erdwerk GmbH for the possibility to carry out such a project and the support during data collection. Additionally, we thank the EnBW AG and especially the Department of Research and Development for the support of the Chair for Geothermal Research of KIT.

Author details

${ }^{1}$ Karlsruher Institute of Technology (KIT), Adenauerring 20b, 76131 Karlsruhe, Germany. ${ }^{2}$ Erdwerk GmbH, Bonner Platz 1, 80803 München, Germany. '3tadtwerke München GmbH (SWM), Emmy-Noether-Straße 2, 80992 München, Germany. 
References

Anderson EM. The dynamic of faulting and dyke formation with application to Britain. Edinburgh: Oliver and Boyd; 1951.

Bachmann GH, Mueller M, Weggen K. Evolution of the Molasse Basin (Germany, Switzerland). Tectonophysics. 1987;137(1-4):77-92. doi:10.1016/0040-1951(87)90315-5.

Barton C, Moos M. Geomechanical wellbore imaging: key to managing the asset life cycle. In: Poppelreiter MG-CC, Kraaijveld M, editors. Dipmeter and Borehole Image Log Technology. AAPG Memoir, vol 92. 2010. p 81-112. doi:10.1306/13181279M922689.

Barton CA, Zoback MD, Moos D. Fluid-flow along potentially active faults in crystalline rock. Geology. 1995;23(8):683-6. doi:10.1130/0091-7613(1995)023 < 0683:Ffapaf > 2.3.Co;2.

Bell JS. Petro Geoscience 1. In situ stresses in sedimentary rocks (part 1): measurement techniques. Geosci Can. 1996a;23(2):85-100. doi:10.12789/gs.v23i2.3902.

Bell JS. Petro Geoscience 2. In situ stresses in sedimentary rocks (part 2): applications of stress measurements. Geosci Can. 1996b;23(3):135-53. doi:10.12789/gs.v23i3.3910.

Bell JS, Gough DI. Northeast-Southwest compressive stress in Alberta - evidence from oil wells. Earth Planet Sc Lett. 1979;45(2):475-82. doi:10.1016/0012-821x(79)90146-8

Betz D, Wendt A. Neuere Ergebnisse der Aufschluss- und Gewinnungstätigkeiten auf Erdöl und Erdgas in Sueddeutschland. Bulletin Verein Schweizer Petroleum-Geologen und -Ingenieure. 1983:49(117):9-36.

Boehm F, Savvatis A, Steiner U, Schneider M, Koch R. Lithofacies and characterization of the geothermal Malm reservoir in the greater area of Munich. Grundwasser. 2012;18(1):3-13. doi:10.1007/s00767-012-0202-4.

Byerlee J. Friction of rocks. Pure Appl Geophys. 1978;116(4-5):615-26. doi:10.1007/Bf00876528.

Davatzes NC, Hickman SH. Stress, fracture, and fluid-flow analysis using acoustic and electrical image logs in hot fractured granites of the Coso Geothermal Field, California, U.S.A. In: Pöppelreiter M, García-Carballido C, Kraaijveld M, editors. Dipmeter and borehole image log technology. AAPG Memoir, vol 92. 2010. p 259-293. doi:10.1306/13181288M923134.

Dorsch K, Pletl C. Bayerisches Molassebecken - Erfolgsregion der Tiefengeothermie in Mitteleuropa. Geothermische Energie. 2012;73:14-8

Faulds JE, Hinz NH, Coolbaugh MF, Cashman PH, Kratt C, Derling G, et al. Assessment of favorable structural settings of geothermal systems in the Great Basin. San Diego, California, USA: Western USA. Paper presented at the Geothermal Resources Council Transactions; 2011.

Fjaer E, Holt RM, Horsrud P, Raaen AM, Risnes R. Petroleum related rock mechanics, vol. 2. Amsterdam, Netherlands: Elsevier; 2008

GTV (2014) Liste der tiefen Geothermieprojekte in Deutschland. www.geothermie.de/fileadmin/useruploads/wissenswelt/ Projekte/Projektliste_Tiefe_Geothermie_2014_alphabetisch.pdf. Accessed 12.062014

Hickman SH, Zoback MD. Stress orientation and magnitudes in the SAFOD pilot hole. Geophys Res Lett. 2004;31. doi:10.1029/2004GL020043.

Hiramatu Y, Oka Y. Determination of stress in rock unaffected by boreholes or drifts from measured strains or deformations. Int J Rock Mech Min. 1968;5(4):337-53. doi:10.1016/0148-9062(68)90005-3.

Homberg C, Hu JC, Angelier J, Bergerat F, Lacombe O. Characterization of stress perturbations near major fault zones: insights from 2-D distinct-element numerical modelling and field studies (Jura Mountains). J Struct Geol. 1997;19(5):703-18. doi:10.1016/S0191-8141(96)00104-6.

Hubbert MK, Willis DG. Mechanics of hydraulic fracturing. AIME: Petroleum Transaction; 1972. p. 210.

Illies JH, Baumann H, Hoffers B. Stress pattern and strain release in the Alpine Foreland. Tectonophysics. 1981;71(1-4):157-72. doi:10.1016/0040-1951(81)90059-7.

Jaeger J, Cook NG, Zimmerman R. Fundamentals of rock mechanics. Malden: Blackwell Pub.: 2007.

Kirsch G. Die Theorie der Elastizität und die Bedürfnisse der Festigkeitslehre. Zeitschrift des Vereins deutscher Ingenieure. 1898:42:797-807.

Kraemer C. Identifikation horizontaler Blattverschiebungen im Untergrund des Molassetrogs - neue Interpretationsergebnisse auf Grundlage von 2D-Seismik. Paper presented at the Geothermiekongress. Germany: Bochum; 2009.

Kuhlemann J, Kempf O. Post-Eocene evolution of the North Alpine Foreland Basin and its response to Alpine tectonics. Sediment Geol. 2002;152(1-2):45-78. doi:10.1016/S0037-0738(01)00285-8.

Lemcke K. Geologie von Bayern - Das bayerische Alpenvorland vor der Eiszeit. Stuttgart: E. Schweizerbart' sche Verlagsbuchhandlung; 1988

Lueschen E, Wolfgramm M, Fritzer T, Dussel M, Thomas R, Schulz R. 3D seismic survey explores geothermal targets for reservoir characterization at Unterhaching, Munich, Germany. Geothermics. 2014;50:167-79. doi:10.1016/j.geothermics.2013.09.007.

Mardia KV. Statistics of directional data: probability and mathematical statistics. London: London Academic Press; 1972.

Mastin L. Effect of borehole deviation on breakout orientation. J Geophys Res. 1988;93(B3):9187-95. doi:10.1029/ JB093iB08p09187.

Megies T, Wassermann J. Microseismicity observed at a non-pressure-stimulated geothermal power plant. Geothermics. 2014;52:36-49. doi:10.1016/j.geothermics.2014.01.002

Meyer RKF, Schmidt-Kaler H. Paläogeographischer Atlas des sueddeutschen Oberjura (Malm), vol. 115. Hannover: Geologisches Jahrbuch; 1989.

Mueller M, Nieberding F, Wanninger A. Tectonic style and pressure distribution at the Northern Margin of the Alps between Lake Constance and the River Inn. Geol Rundsch. 1988;77(3):787-96. doi:10.1007/Bf01830185.

Peska P, Zoback MD. Compressive and tensile failure of inclined well bores and determination of in situ stress and rock strength. J Geophys Res-Sol Ea. 1995;100(B7):12791-811. doi:10.1029/95jb00319.

Pletl C, Stoyke R, Toll H. Bohrerfahrungen bei Sueddeutschlands größtem. Geothermieprojekt bbr. 2010;3:38-47.

Reinecker J, Tingay M, Mueller B. Borehole breakout analysis from four-arm caliper logs. World stress analysis Guidelines. www.world-stress-map.org

Reinecker J, Tingay M, Mueller B, Heidbach O. Present-day stress orientation in the Molasse Basin. Tectonophysics. 2010;482(1-4):129-38. doi:10.1016/j.tecto.2009.07.021.

Savvatis A. Personal communication of well analyses. 2014 
Schulz R, Agemar T, Alten J-A, Brunken J, Heber M, Kuder J, et al. Aufbau eines geothermischen Informationssystems für Deutschland. Hannover: Leibniz-Institut für Angewandte Geophysik; 2009.

Shamir G, Zoback MD. Stress orientation profile to $3.5 \mathrm{~km}$ depth near the San Andreas Fault at Cajon Pass, California. J Geophys Res. 1992;97(B4):5059-80. doi:10.1029/91JB02959.

Sibson RH. Frictional constraints on thrust, wrench and normal faults. Nature. 1974;249:542-4. doi:10.1038/249542a0, Steiner U, Savvatis A, Boehm F, Schubert A. Explorationsstrategie tiefer geothermischer Ressourcen am Beispiel des sueddeutschen Oberjuras (Malm). In: Bauer M, Freeden W, Jacobi H, editors. Handbuch Tiefe Geothermie. Berlin Heidelberg: Springer Spektrum Verlag; 2014. p. 429-57. doi:101007/978-3-642-54511-5.

Stier P, Prestel R. Der Malmkarst im süddeutschen Molassebecken - Ein hydrogeologischer Überblick. In: LfW B, LGR B, editors. Hydrogeologische Energiebilanz und Grundwasserhaushalt des Malmkarsts im süddeutschen Molassebeckens, vol. 03E-6240 A/B. München: Schlussbericht zum Forschungsvorhaben; 1991. p. 12.

STWIVT. Bayerischer Geothermieatlas - Hydrothermale Ernergiegewinnung. München: Bayerisches Staatsministerium für Wirtschaft Infrastruktur Verkehr und Technologie (STWIVT); 2010.

Sylvester AG. Strike-slip faults. Geol Soc Am Bull. 1988;100(11):1666-703. doi:10.1130/0016-7606(1988)100 < 1666:Ssf > 2.3.Co;2.

Terzaghi RD. Sources of error in joint surveys. Geotechnique. 1965;15(3):287-304. doi:10.1680/geot.1965.15.3.287.

Tingay M, Mueller B, Reinecker J, Heidbach O. State and origin of the present-day stress field in sedimentary basins: new results from the World Stress Map Project, Paper presented at the Golden Rocks 2006. Colorado, USA: The 41st U.S. Symposium on Rock Mechanics (USRMS), 17-21 June, Golden; 2006.

Trice R. A methodology for applying a non unique, morphological classification to sine wave events picked from borehole image log data. In: Lovell MAWG, Harvey PK, editors. Borehole imaging: applications and case histories, vol special publications. London: Geological Society; 1999. p. 77-90. doi:10.1144/GSL.SP.1999.159.01.04.

Unger H-J. Die tektonischen Strukturen der bayerischen Ostmolasse. Documenta Naturae. 1999;124:1-16.

Wagner D, Mueller B, Tingay M. Correction for tool decentralisation of oriented six-arm caliper logs for determination of contemporary tectonic stress orientation. Petrophysics. 2004;42:1049-76.

Ziegler PA. Compressional intra-plate deformation in the Alpine Foreland - an introduction. Tectonophysics. 1987;137:1-5. doi:10.1016/0040-1951(87)90223-X.

Zoback MD. Reservoir geomechanics. Cambridge: Cambridge University Press. 2007.

Zoback MD, Barton CA, Brudy M, Castillo DA, Finkbeiner T, Grollimund BR, et al. Determination of stress orientation and magnitude in deep wells. Int J Rock Mech Min. 2003;40(7-8):1049-76. doi:10.1016/j.jirmms.2003.07.001.

Zoback ML. 1st-order and 2nd-order patterns of stress in the lithosphere - the World Stress Map Project. J Geophys Res-Sol Ea. 1992;97(B8):11703-28. doi:10.1029/92jb00132.

\section{Submit your manuscript to a SpringerOpen ${ }^{\circ}$ journal and benefit from:}

- Convenient online submission

Rigorous peer review

- Immediate publication on acceptance

- Open access: articles freely available online

- High visibility within the field

- Retaining the copyright to your article 